\title{
The cellular and molecular mechanisms of immuno-suppression by human type 1 regulatory T cells
}

\author{
Silvia Gregori ${ }^{1 \dagger}$, Kevin S. Goudy ${ }^{1 \dagger}$ and Maria Grazia Roncarolo ${ }^{1,2} *$ \\ ' Division of Regenerative Medicine, Stem Cells and Gene Therapy, San Raffaele Telethon Institute for Gene Therapy (HSR-TIGET), San Raffaele Scientific Institute, \\ Milan, Italy \\ ${ }^{2}$ Vita-Salute San Raffaele University, Milan, Italy
}

\section{Edited by:}

Kendall A. Smith, Weill Medical

College of Cornell University, USA

\section{Reviewed by:}

Kendall A. Smith, Weill Medical

College of Cornell University, USA

António Castro, University of Minho, Portugal

Nikolai Petrovsky, Flinders Medical

Centre, Australia

*Correspondence:

Maria Grazia Roncarolo, Division of Regenerative Medicine, San Raffaele Telethon Institute for Gene Therapy (HSR-TIGET), Via Olgettina 58, 20132

Milan, Italy.

e-mail:m.roncarolo@hsr.it

${ }^{+}$Silvia Gregori and Kevin S. Goudy

have contributed equally to this work.
The immuno-regulatory mechanisms of IL-10-producing type 1 regulatory $T$ ( $\operatorname{Tr} 1$ ) cells have been widely studied over the years. However, several recent discoveries have shed new light on the cellular and molecular mechanisms that human Tr1 cells use to control immune responses and induce tolerance. In this review we outline the well known and newly discovered regulatory properties of human $\operatorname{Tr} 1$ cells and provide an in-depth comparison of the known suppressor mechanisms of Tr1 cells with $\mathrm{FOXP}^{+} \mathrm{T}_{\text {reg. }}$. We also highlight the role that $\operatorname{Tr} 1$ cells play in promoting and maintaining tolerance in autoimmunity, allergy, and transplantation.

Keywords: IL-10, Tr1 cells, immunotolerance, $\mathrm{FOXP3}^{+} \mathbf{T}_{\text {reg }}$

\section{INTRODUCTION}

The original study that led to the discovery of interleukin (IL)10-producing type 1 regulatory $\mathrm{T}(\operatorname{Tr} 1)$ cells began in the late eighties when the immune system of a severe combined immunodeficiency (SCID) patient, who developed long-term mixed chimerism after HLA-mismatched fetal liver hematopoietic stem cell transplant (HSCT), was analyzed to understand how tolerance was acquired. This patient did not develop graft-versus-host disease (GvHD) in the absence of immunosuppressive therapy, despite having host-specific $\mathrm{CD} 4^{+} \mathrm{T}$ helper and $\mathrm{CD} 8^{+}$cytolytic $\mathrm{T}$ cells of donor origin, suggesting that an allo-regulatory suppressor mechanism(s) was responsible for maintaining tolerance (Roncarolo et al., 1988). Interestingly, allo-reactive $\mathrm{CD}^{+} \mathrm{T}$ cell clones isolated from this transplanted patient had a cytokine profile distinct from both type 1 and type 2 helper T cells (Th1 and Th2, respectively), since they produced IL-5, IFN- $\gamma$, and GM-CSF, low levels of IL-2, but not IL-4 (Bacchetta et al., 2002), suggesting that these $\mathrm{T}$ cell clones were a unique population of $\mathrm{T}$ cells. Pursuant to the cloning of human IL-10 (Vieira et al., 1991), a second tolerant SCID patient who underwent HLA-mismatched HSCT was found to have high plasma levels of IL-10, and a significant proportion of donor-derived $\mathrm{CD} 4^{+} \mathrm{T}$ cell clones specific for the host HLA antigen (Ag)s that produced IL-10 at high levels (Bacchetta et al., 1994). A few years later, Groux et al. (1997) demonstrated in mice and humans that IL-10-producing $\mathrm{CD}^{+} \mathrm{T}$ cells, are indeed, a distinct subset of $\mathrm{T}$ cells that are Ag-specific and immunosuppressive and can mediate immunetolerance. Together, these findings led to a new classification of
IL-10-producing $\mathrm{CD} 4^{+} \mathrm{T}$ cells appropriately named $\mathrm{Tr} 1$ cells. Since their seminal discovery, a finding that predates the identification of the more widely studied $\mathrm{CD} 4{ }^{+} \mathrm{CD} 25^{+}$regulatory $\mathrm{T}$ cells $\left(\mathrm{T}_{\text {reg }}\right)$ (Sakaguchi et al., 1995), Trl cells have proven to be important in mediating tolerance in several $\mathrm{T}$ cell mediated diseases (review in Roncarolo et al., 2006, 2011; Roncarolo and Battaglia, 2007).

Apart from being detected in SCID patients after allogeneic HSCT (Bacchetta et al., 1994), Tr1 cells have been described in $\beta$ thalassemic patients who developed persistent mixed chimerism (Serafini et al., 2009). These tolerant $\beta$-thalassemic patients had high levels of IL-10 in peripheral blood and an increased percentage of IL-10-producing $\mathrm{CD}^{+} \mathrm{T}$ cells compared to normal donors. Moreover, allo-specific $\operatorname{Tr} 1$ cell clones isolated from patients' peripheral blood suppressed alloAg-specific $\mathrm{T}$ cell proliferation and cytokine production in an IL-10 dependent manner (Serafini et al., 2009). Overall, the results from tolerant HSCT patients indicate that $\operatorname{Tr} 1$ cells are associated with long-term chimerism, possibly induced through chronic exposure to alloAgs after transplantation.

Interleukin-10-producing $\operatorname{Tr} 1$ cells have also been demonstrated in an array of different immune-mediated diseases. For example, Tr 1 cells specific for self-Ags such as desmoglein 3 and islet Ags have been described in pemphigus patients (Veldman et al., 2004) and diabetes patients (Tree et al., 2010), respectively. Furthermore, Tr1 cells specific for the foreign-Ags gliadin in celiac disease (Gianfrani et al., 2006), and for nickel (Cavani et al., 2000), Derp 1 (Akdis et al., 2004), and bee-venom (Meiler et al., 2008) 
in allergic patients have been reported. Conversely, the absence of Tr1 cells in acute viral infections correlates with clearance of the virus, while the presence of $\operatorname{Tr} 1$ cells is associated with viral persistence in chronic viral infections such as HIV, HCV, and HBV (Granelli-Piperno et al., 2004; Ha et al., 2008), and in bacterial infections such as Bordetella pertussis (McGuirk et al., 2002) and Mycobacterium tuberculosis (Boussiotis et al., 2000; McGuirk et al., 2002).

In this review we provide an overview of the similarities and differences between human $\operatorname{Tr} 1$ cells and forkhead box P3 (FOXP3)-expressing CD4 ${ }^{+} \mathrm{CD} 25^{+} \mathrm{T}_{\text {reg }}$ cells (FOXP3 ${ }^{+} \mathrm{T}_{\text {reg }}$ ) by summarizing their cellular and molecular suppressive mechanisms and describe the current knowledge of their safety and efficacy in clinical trials.

\section{$T_{\text {reg }}$ SUBSETS: DIFFERENT CELLS SHARING SIMILAR MARKERS}

Regulatory $\mathrm{T}$ cells are a fundamental component of a healthy immune system since they play a vital role in fine-tuning the balance between effector and tolerogenic immune responses. It is well documented that a deficiency in $\mathrm{T}_{\text {reg }}$ frequency or number, or a defect in their function can lead to inflammation and/or autoimmune diseases (Roncarolo and Levings, 2000; Roncarolo and Battaglia, 2007; Sakaguchi et al., 2008). Over the years, several types of $\mathrm{T}_{\text {reg }}$ populations have been identified: TGF- $\beta$ secreting, Type 3 helper cells (Th3; Miller et al., 1992), CD8 ${ }^{+}$CD28 ${ }^{-}$T cells (Liu et al., 1998), HLA-E-specific CD8 ${ }^{+}$T cells (Jiang et al., 2010), etc. but, to date, the best characterized are the FOXP3 ${ }^{+} \mathrm{T}_{\text {reg }}$ (Hori et al., 2003; Khattri et al., 2003) and the CD4 ${ }^{+}$IL-10-producing $\operatorname{Tr} 1$ cells (Groux et al., 1997; Barrat et al., 2002; Akdis et al., 2004). Their distinct intracellular and surface markers and cytokine expression profile distinguish FOXP3 ${ }^{+} \mathrm{T}_{\text {reg }}$ and $\mathrm{Tr} 1$ cells from one another. $\mathrm{FOXP}^{+} \mathrm{T}_{\text {reg }}$ are identified by standard flow cytometry techniques based on their constitutively high expression of CD25 and the transcription factor FOXP3 (Sakaguchi, 2005). FOXP3 ${ }^{+} \mathrm{T}_{\text {reg }}$ can be subcategorized into naturally occurring FOXP3 ${ }^{+} \mathrm{T}_{\text {reg }}$ (Yagi et al., 2004), which are selected in the thymus, and adaptive FOXP3 ${ }^{+}$ $\mathrm{T}_{\text {reg }}$ (Fantini et al., 2004; Tran et al., 2007; Horwitz et al., 2008; Lu et al., 2010) that are induced in the periphery, based on the surface expression of Helios, which is found only on the former population (Thornton et al., 2010). In addition, the naturally occurring FOXP3 ${ }^{+} \mathrm{T}_{\text {reg }}$ are identified and distinguished from activated $\mathrm{CD} 4^{+} \mathrm{T}$ cells by the expression of low levels of CD127 (Liu et al., 2006; Seddiki et al., 2006), and of CD49d (Kleinewietfeld et al., 2009), and by the DNA demethylation of a specific region of the FOXP3 gene called $\mathrm{T}_{\text {reg }}$-specific demethylated region (TSDR; Baron et al., 2007). Furthermore, the expression of CD45RA distinguishes naïve from activated $\mathrm{FOXP} 3^{+} \mathrm{T}_{\text {reg }}$ and from activated conventional CD4 ${ }^{+}$T cells (Hoffmann et al., 2006; Miyara et al., 2009).

Type 1 regulatory $\mathrm{T}$ cells, on the other hand, are a more discrete population of $\mathrm{T}_{\text {reg }}$ that are induced in the periphery which, to date, lack a define cell surface signature. Similar to other human effector T cells (Allan et al., 2007; Passerini et al., 2008), Tr1 cells transiently express FOXP3 upon activation (Levings et al., 2005, and S. Gregori and M. G. Roncarolo, personal communication); however, FOXP3 expression in Tr1 cells is not maintained after activation and never reaches the high expression levels characteristic of FOXP3 ${ }^{+} \mathrm{T}_{\text {reg. }}$. Furthermore, FOXP3 is not required for $\operatorname{Tr} 1$ cell induction or function since suppressive $\operatorname{Tr} 1$ cells can be generated or isolated from peripheral blood of patients with immunedysregulation polyendocrinopathy enteropathy Xlinked (IPEX), a disease condition due to FOXP3-mutations, even in those patients with complete deletion of FOXP3 (Passerini et al., 2011). The rapid onset of autoimmune-mediated wasting disease after birth in IPEX patients indicates that, although $\operatorname{Tr} 1$ cells can be induced they are not present or sufficient to control aggressive autoimmunity early in life. The naturally occurring FOXP3 ${ }^{+} \mathrm{T}_{\text {reg }}$, which are present from birth, are immediately effective especially to modulate self-reactivity, whereas $\operatorname{Tr} 1$ cells are induced in the periphery and are involved in regulation later on in life. Therefore, $\operatorname{Tr} 1$ cells and naturally occurring $\mathrm{FOXP}^{+} \mathrm{T}_{\text {reg }}$ in humans are distinct subsets of cells with regulatory activity that co-operate in promoting and controlling tolerance in vivo.

Type 1 regulatory $T$ cells are currently identified by their unique cytokine profile consisting of high levels of IL-10, TGF- $\beta$, low levels of IL-2, variable levels of IL- 5 and IFN- $\gamma$, in the absence of IL-4 after stimulation (Groux et al., 1997). The reliance on a cytokine profile to distinguish $\operatorname{Tr} 1$ cells from other $T$ cell subsets complicates their identification and study since $\operatorname{Tr} 1$ cells are not the only T cell subset that secretes IL-10. Other T cell subsets such as FOXP3 ${ }^{+}$ $\mathrm{T}_{\text {reg }}$ (Ito et al., 2008), Th1 and Th2 cells (Yssel et al., 1992; Del Prete et al., 1993; Chang et al., 2007; Saraiva et al., 2009), Th9 (Veldhoen et al., 2008), and Th17 (McGeachy et al., 2007) can also express IL-10, depending on stimulation and environmental conditions. For example, the strong stimulation of Th1 cells via $\mathrm{T}$ cell receptor (TCR) in the presence of high levels of IL12 p70 can result in the induction of IL-10 production (Gerosa et al., 1996); however it is unclear if the induced IL-10 expression remains fixed once the environmental stimuli is removed. $\operatorname{Tr} 1$ cell clones display a distinct kinetics of IL-10 secretion, since IL-10 is detectable in culture supernatants at high concentrations early after Ag-specific activation and is maintained over the life of the cell (Bacchetta et al., 1994), whereas IL-10 production by either Th cell clones or peripheral blood cells occurs late after stimulation and never reaches the level of Tr1 cells (Yssel et al., 1992; de Waal Malefyt et al., 1993). The reason why $\operatorname{Tr} 1$ cells are able to secrete high levels of IL-10 shortly after activation is unknown; however, it is possible that the high levels of IL-10 secretion is a result of chromatin remodeling at the IL-10 locus, which allows $\operatorname{Tr} 1$ cells to readily secrete IL-10 upon activation and to bypass IL-10 repression (Trinchieri, 2007). Answering this question will help to determine if $\operatorname{Tr} 1$ cells are a truly fixed lineage of cells or if $\operatorname{Tr} 1$ cells are plastic like the other $\mathrm{T}$ cell subsets such as $\mathrm{FOXP}^{+} \mathrm{T}_{\text {reg. }}$.

Several groups, including ours, aimed at identifying markers specific for $\operatorname{Tr} 1$ cells that distinguish them from other $\mathrm{CD}^{+}{ }^{+} \mathrm{T}$ cell subsets. Thus far, a number of candidate molecules have been proposed, but unfortunately, most of them are not specific for $\operatorname{Tr} 1$ cells. For example, a recent report indicated that the surface expression of lymphocyte activation gene-3 (LAG-3) on $\mathrm{CD} 4{ }^{+}$ $\mathrm{T}$ cell correlates with IL-10 production and possibly $\operatorname{Tr} 1$ cells (Okamura et al., 2009); however, LAG-3 has been shown to be 
Table 1 | Proposed markers of human Tr1 cells.

\begin{tabular}{|c|c|c|c|c|}
\hline \multirow[t]{2}{*}{ Molecule } & \multicolumn{3}{|c|}{ Tr1 cells } & \multirow[t]{2}{*}{ Other cell types } \\
\hline & Resting & Activated & Specific & \\
\hline ICOS & Yes & Yes $\uparrow$ & No & FOXP3 $^{+} \mathrm{T}_{\text {reg }}$ (lto et al., 2008) \\
\hline PD-1 & Yes & Yes $\uparrow$ & No & $\begin{array}{l}\text { FOXP3 }^{+} \mathrm{T}_{\text {reg }} \text { (Raimondi et al., 2006) } \\
\text { Tfh (Yu et al., 2009) }\end{array}$ \\
\hline p-STAT3 & Yes & Yes $\uparrow$ & No & $\begin{array}{l}\text { Th17 (de Beaucoudrey et al., 2008) } \\
\text { Tfh (Schmitt et al., 2009) }\end{array}$ \\
\hline C-MAF & Yes & $?$ & No & $\begin{array}{l}\text { Th2 (Rani et al., 2011) } \\
\text { Th17 (Hiramatsu et al., 2010) }\end{array}$ \\
\hline AhR & Yes & $?$ & No & $\begin{array}{l}\text { Th17 Neldhoen et al., 2008) } \\
\text { Th22 (Trifari et al., 2009) }\end{array}$ \\
\hline
\end{tabular}

$\uparrow$, high level of expression; ?, indicates that data is not determined.

associated with $\mathrm{FOXP}^{+}{ }^{+} \mathrm{T}_{\text {reg }}$ (Camisaschi et al., 2010), making LAG-3 an undependable marker for distinguishing $\operatorname{Tr} 1$ cells from other $\mathrm{T}_{\text {reg }}$ subsets. Similar to LAG-3, other proposed biomarkers for $\operatorname{Tr} 1$ cells, such as inducible co-stimulatory molecule (ICOS; Haringer et al., 2009), and programmed death receptor 1 (PD-1; Akdis et al., 2004) have been associated with IL-10-producing T cells, but, here again, they are also found on other $\mathrm{T}$ cell subsets. Another report described the combined expression of the integrins $\mathrm{CD} 18^{\text {high }}$ and $\mathrm{CD} 49 \mathrm{~b}$ as $\operatorname{Tr} 1$ cell-specific markers in peripheral blood of healthy donors (Charbonnier et al., 2006; Rahmoun et al., 2006). Unpublished results from our group also show that $\operatorname{Tr} 1$ cell clones isolated from normal donors express higher levels of CD49b compared to Th0 clones, whereas CD18 is expressed at similar levels (Gagliani and Gregori, unpublished). In addition to surface molecules, transcription factors known to regulate IL-10 expression such as STAT3 (Levings et al., 2001a), C-MAF (Pot et al., 2009), and aryl hydrocarbon receptor (AhR; Apetoh et al., 2010) have been used to identify human IL-10-producing $\mathrm{T}$ cells, but it is still unclear if these transcription factors can be considered master regulators and bona fide markers for Tr 1 cells (Table 1 for summary of proposed markers). These data indicate that several markers correlate with IL-10-producing T cells, but the search for a unique and specific marker for human $\operatorname{Tr} 1$ cells has been as of today not fruitful. Several studies, including gene expression profiling using ex vivo isolated $\operatorname{Tr} 1$ cell clones and in vitro generated $\operatorname{Tr} 1$ cells, are ongoing to identify $\operatorname{Tr} 1$ specific markers.

\section{$T_{\text {reg }}$ SUBSETS: DIFFERENT CELLS SHARING SIMILAR MECHANISMS OF SUPPRESSION \\ MECHANISMS OF FOXP3 ${ }^{+} T_{\text {reg }}$ SUPPRESSION}

Both naturally occurring and induced FOXP3 ${ }^{+} \mathrm{T}_{\text {reg }}$ suppress immune responses through several mechanisms, which can be grouped into five basic modes of action: (i) cell-to-cell contact, (ii) modulation of dendritic cells (DC), (iii) secretion of inhibitory cytokines, (iv) metabolic disruption, and (v) cytolysis (review in Vignali, 2008).
FOXP3 $^{+} \mathrm{T}_{\text {reg }}$ suppress effector $\mathrm{T}$ cell responses through still not completely elucidated cell-to-cell contact dependent mechanisms (Takahashi et al., 1998; Thornton and Shevach, 1998). Nonetheless, it has been demonstrated that FOXP3 ${ }^{+} \mathrm{T}_{\text {reg }}$ requires TCR activation (Thornton and Shevach, 2000) and IL-2 (Thornton et al., 2004b) to exert their suppressive functions. The means by which FOXP3 ${ }^{+} \mathrm{T}_{\text {reg }}$ suppress is through the transcriptional inhibition of IL-2 in effector T cells (Thornton and Shevach, 1998; Thornton et al., 2004a) and IL-2 consumption (de la Rosa et al., 2004). The molecular mechanisms underlying the suppression of IL-2 mRNA in effector T cells is still unknown; however, it is independent of TGF- $\beta$ /IL-10 or IL- 2 consumption (Oberle et al., 2007).

Modulation of DC function is another means by which FOXP3 $^{+} \mathrm{T}_{\text {reg }}$ control $\mathrm{T}$ cell proliferation. FOXP3 ${ }^{+} \mathrm{T}_{\text {reg }}$ regulate the catabolic enzyme indoleamine 2,3-dioxygenase (IDO) on DC through the interaction of Cytotoxic T-Lymphocyte Antigen 4 (CTLA-4) with CD80/86 (Fallarino et al., 2003; Munn et al., 2004). IDO inhibits effector T cell proliferation by reducing tryptophan, which is necessary for cell division. In addition, FOXP3 ${ }^{+}$ $\mathrm{T}_{\text {reg }}$ can prevent DC activation by sending inhibitory signals to the DC through the interaction of LAG-3 with the MHC class II molecules (Liang et al., 2008).

FOXP3 $^{+} \mathrm{T}_{\text {reg }}$ secrete regulatory cytokines IL-10 (Ito et al., 2008), TGF- $\beta$ (Levings et al., 2001b; Stockis et al., 2009; Wang et al., 2009), and IL-35 (Chaturvedi et al., 2011). While IL-10, TGF- $\beta$, and IL-35 expression have been shown to be involved in suppression mediated by human FOXP3 ${ }^{+} \mathrm{T}_{\text {reg }}$ in vitro, it remains to be defined whether these cytokines contribute to their suppressive function in vivo.

$\mathrm{FOXP}^{+}{ }^{+} \mathrm{T}_{\text {reg }}$ can also generate adenosine via the enzymatic hydrolysis of extracellular ATP by the ectoenzymes CD39 and CD73 (Deaglio et al., 2007), which disrupt the metabolic state of effector $\mathrm{T}$ cells. Adenosine upon binding to its receptor, the adenosine-specific A2A receptor (Borsellino et al., 2007), suppresses inflammatory cytokine secretion by effector $\mathrm{T}$ cells in a cyclic AMP (cAMP) dependent fashion (Bopp et al., 2007). 
Killing of target cells via the secretion of granzymes (Gzs) is a well known feature of natural killer $(\mathrm{NK})$ and cytotoxic $\mathrm{CD}^{+}$ T cells (Cullen and Martin, 2008), but it is now evident that also $\mathrm{CD}^{+} \mathrm{T}$ cells, including FOXP3 ${ }^{+} \mathrm{T}_{\text {reg }}$, can use Gzs to kill cells. Upon activation FOXP3 ${ }^{+} \mathrm{T}_{\text {reg }}$ express GzA and can lyse target cells of both myeloid and lymphoid origin. Lysis mediated by FOXP3 ${ }^{+}$ $\mathrm{T}_{\text {reg }}$ requires CD18-mediated adhesion (Grossman et al., 2004a).

\section{MECHANISMS OF Tr1-MEDIATED SUPPRESSION}

Although multiple mechanisms of $\operatorname{Tr} 1$-mediated suppression have been identified (Roncarolo et al., 2006), the relative importance of each mechanism in vivo remains to be defined since most of the studies regarding human $\operatorname{Tr} 1$ cell activity have been done in vitro. The main mechanism by which $\operatorname{Tr} 1$ cells mediate immune suppression and promote tolerance is cytokine-mediated. However, new evidences suggest that $\operatorname{Tr} 1$ cells are multifaceted suppressors that use several modes of immune regulation to achieve tolerance. $\operatorname{Tr} 1$ cells indeed can inhibit $\mathrm{T}$ cell responses by cell contact dependent mechanisms (Akdis et al., 2004), metabolic disruption (Mandapathil et al., 2010), and cytolysis (Grossman et al., 2004b; Magnani et al., 2011; see Table 2 for a summary of proposed $\operatorname{Tr} 1$ cells suppressive functions).

\section{CYTOKINE-MEDIATED MECHANISMS OF SUPPRESSION BY Tr1 CELLS}

The chief mechanism by which $\mathrm{Tr} 1$ cells control immune responses is through the secretion of high levels of the immunosuppressive cytokines IL-10 and TGF- $\beta$ (Bacchetta et al., 1994; Groux et al., 1997; Barrat et al., 2002; Veldman et al., 2004). IL-10

Table 2 | Mode of suppression mediated by Tr 1 cells and/or FOXP3 $^{+} \mathrm{T}_{\text {reg }}$.

\begin{tabular}{lll}
\hline & Tr1 cells & FOXP3 $^{+} \mathbf{T}_{\text {reg }}$ \\
\hline CYTOKINES & Yes & Still controversial (Ito et al., \\
IL-10 & 2008) \\
& Yes & Yes (Levings et al., 2001 b) \\
TGF- $\beta$ & Undefined & Yes (Chaturvedi et al., 2011) \\
IL-35 & Yes & Yes (Fallarino et al., 2003) \\
CELL-TO-CELL CONTACT & Undefined \\
CTLA-4 & Yes & Yes for murine cells (Liang \\
PD-1 & Undefined & et al., 2008) \\
LAG-3 & & Undefined for human cells \\
& & Undefined \\
ICOS & Undefined & Yes (Levings et al., 2001 b; \\
LAP & Undefined & Stockis et al., 2009; Wang \\
& & et al., 2009) \\
& & \\
METABOLIC DISRUPTION & Possible & Yes (Borsellino et al., 2007) \\
CD39 and CD73 & Undefined & Yes for murine cells (Bopp \\
cAMP & & et al., 2007) \\
& & Undefined for human cells \\
CYTOLYSIS & No & Yes (Grossman et al., 2004b) \\
Granzyme A/perforin & No (Grossman et al., 2004a) \\
Granzyme-B/perforin & Yes &
\end{tabular}

directly suppresses $\mathrm{T}$ cell responses by inhibiting IL-2, IFN- $\gamma$, and GM-CSF production by T cells (Vieira et al., 1991) and by preventing proliferation (Taga and Tosato, 1992). Similarly, TGF$\beta$ has potent immune-modulatory effects that directly inhibit $\mathrm{T}$ cell responses (Gorelik and Flavell, 2002; Gorelik et al., 2002; Figure 1A). Together, IL-10 and TGF- $\beta$ secreted by Tr 1 cell lines or clones can inhibit IFN- $\gamma$ production by $\mathrm{T}$ effector cells and limit their proliferation (Cavani et al., 2000; Levings et al., 2005; Meiler et al., 2008; Serafini et al., 2009; Gregori et al., 2010). Whether IL10 and TGF- $\beta$ expressed by Tr 1 cells modulate other effector T cells such as Th9 (Veldhoen et al., 2008), Th17 (Park et al., 2005), Th22 (Trifari et al., 2009), and T follicular helper (Tfh) cells (Crotty, 2011) has yet to be elucidated.

Type 1 regulatory $\mathrm{T}$ cells also suppress effector $\mathrm{T}$ cells indirectly by inhibiting inflammatory factors and activating tolerogenic pathways of antigen-presenting cells (APC; Roncarolo et al., 2006). Many of the molecules hindered by IL-10 on APC, like MHC class II, co-stimulatory molecules (de Waal Malefyt et al., 1991), and pro-inflammatory cytokines (Fiorentino et al., 1991a; Mosser and Zhang, 2008) are important mediators of adaptive immune responses. IL-10 treated APC, which up-regulate a number of tolerogenic molecules, including immunoglobulin-like transcript (ILT)-3 and 4 (Manavalan et al., 2003; Gregori et al., 2010), and the non-classical HLA-G (Moreau et al., 1999; Gregori et al., 2010), become regulatory cells capable of dampening immune responses and inducing $\mathrm{T}_{\text {reg }}$ (Morelli and Thomson, 2007; Gregori, 2011; Figure 1A). For example, IL-10-treated macrophages or DC have reduced abilities to secrete IL-12 after LPS activation and to induce Th1 responses (Fiorentino et al., 1991b). It was demonstrated that in allergic patients nickel-specific Tr1 cells inhibit DC to produce IL-12 after LPS stimulation and nickel-specific Th1 cell responses (Cavani et al., 2000).

B cells are targets of IL-10 and can promote tolerance by secreting specific immunoglobulin subclasses (Scott-Taylor et al., 2010). For example, activation of B cells in the presence of IL-10 prevents apoptosis, enhances their proliferation, differentiation, and $\mathrm{MHC}$ class II expression, and promotes immunoglobulin switching (Go et al., 1990; Sabat, 2010). IL-10 derived from Tr1 cells promotes IgG4 production by B cells (Satoguina et al., 2005), and in an allergy setting, allergen-specific $\operatorname{Tr} 1$ cells induce IgG4 and suppress IgE production via an IL-10-mediated mechanisms (Meiler et al., 2008). Therefore, $\operatorname{Tr} 1$ cells promote tolerance also by modulating B cell functions.

Interleukin-10 produced by $\operatorname{Tr} 1$ cells contributes to the generation of $\mathrm{T}_{\text {reg. }}$. Our group showed that $\mathrm{Ag}$ stimulation of human naïve $\mathrm{CD} 4^{+} \mathrm{T}$ cells in the presence of IL-10 promoted the induction of $\operatorname{Tr} 1$ cells in vitro (Bacchetta et al., 2002, 2010; Gregori et al., 2010). Signaling through the IL-10 receptor (IL-10R) can induce IL-10 production by CD4 ${ }^{+} \mathrm{T}$ cells (Barrat et al., 2002), promote $\mathrm{T}$ cell anergy in $\mathrm{CD}^{+}{ }^{+}$and $\mathrm{CD}^{+}{ }^{+} \mathrm{T}$ cells (Groux et al., 1996, 1998), and $\operatorname{Tr} 1$ cell differentiation (Groux et al., 1997) in a STAT3-dependent manner. The importance of activating the STAT3 pathway to induce $\operatorname{Tr} 1$ cells is highlighted by the fact that other STAT3 activating cytokines such as IL-27 or IFN- $\alpha$ alone (Awasthi et al., 2007; Fitzgerald et al., 2007; Murugaiyan et al., 2009) or in combination with IL-10 (Levings et al., 2001a) promote Tr 1 cells in vitro. Notably, a difference between the induction 


\section{A Cytokine-mediated mechanisms}

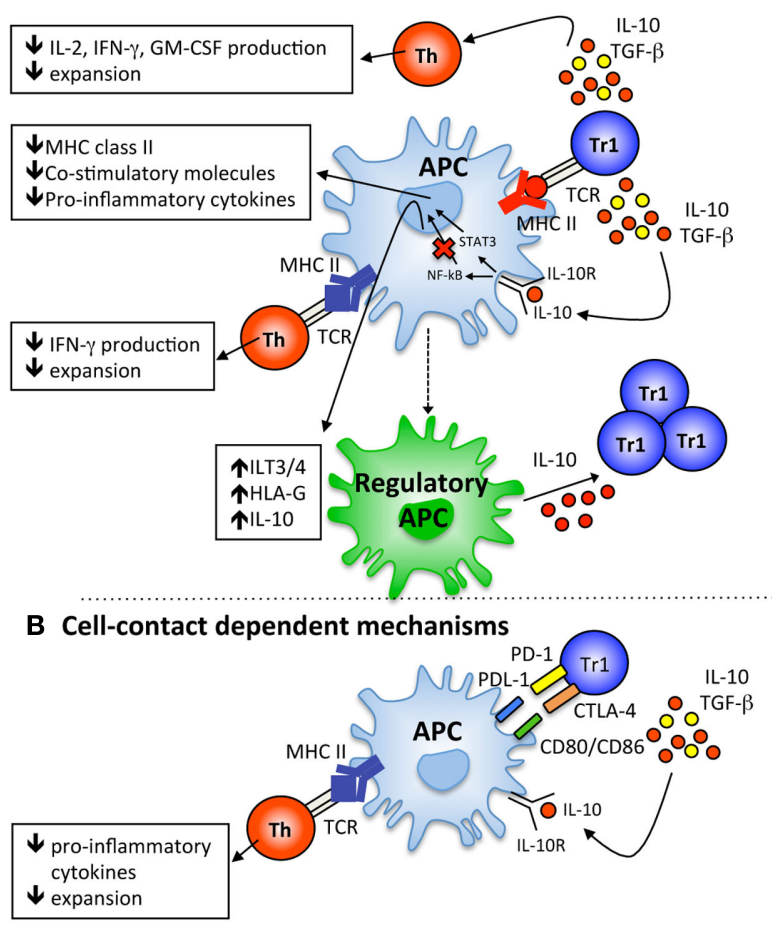

C Metabolic disruption

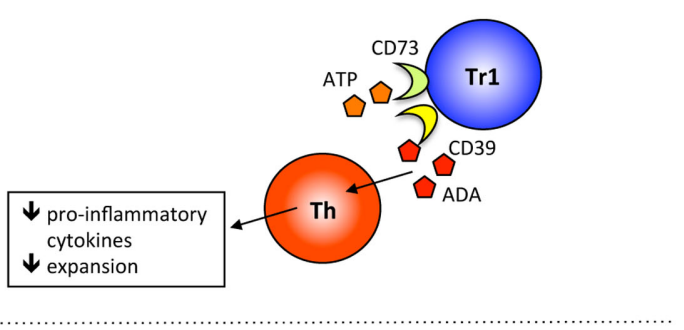

D Cytolitic activity

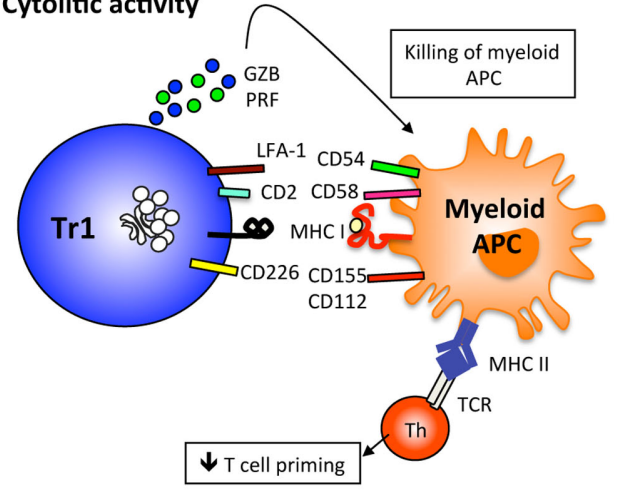

FIGURE 1 | Mechanisms of suppression mediated by Tr1 cells. (A) Tr1 cells upon Ag-specific activation secrete IL-10 and TGF- $\beta$ that directly inhibit the function of effector T cells and indirectly modulate APC, which in turn limit effector T cell proliferation and cytokine production. IL-10 produced by $\operatorname{Tr} 1$ cells up-regulates the expression of tolerogenic molecules (ILT3, ILT4, and HLA-G) on APC and their ability to produce IL-10, and become regulatory APC able to promote de novo induction of $\operatorname{Tr} 1$ cells. (B) CTLA-4 and PD-1 on Tr1 cells down-regulate or prevent the up-regulation of MHC class II and co-stimulatory molecules on APC upon interaction with their ligand, which limits effector T cell activation. (C) Catalytic inactivation of extracellular ATP by the ectoenzymes CD39 and CD73 represents an anti-inflammatory mechanism used by Tr1 cells to prevent effector T cell proliferation and cytokine production. (D) IL-10 produced by $\operatorname{Tr} 1$ cells upon activation promotes autocrine granzyme-B (GZ-B) that in association with perforin (PRF) allows an Ag-non-specific Tr1-mediated killing of myeloid APC. Myeloid-specific killing by Tr1 cells requires HLA class I activation and the expression of CD54, CD58, CD112, and CD155 on myeloid cells. of IL-10 in Tr 1 cells and other IL-10-producing T cells is that IL-10 expression in non-Tr1 cells is STAT3 independent. For instance, IL-10 production by Th1 cells requires strong TCR activation and IL-12p70-induced STAT4 activation (Trinchieri, 2007; Saraiva et al., 2009). Thus, IL-10 production by $\operatorname{Tr} 1$ cells is induced under specific conditions compared to other IL-10-producing T cells and STAT3 activation may represent a key signaling pathway that allows these cells to maintain the expression of IL-10 at high levels.

The binding of IL-10 to its tetrameric, transmembrane IL-10R composed of two IL-10R1 and two IL-10R2 molecules induces the phosphorylation of Jak1 and Tyk 2 within the intracellular domain of IL-10R1, which acts as docking sites for STAT3 (Donnelly et al., 1999). After STAT3 docking and phosphorylation (p-), p-STAT3 homodimerizes in the cytoplasm and then translocates to the nucleus, where it binds to STAT3-binding elements in the promoters of various genes, including IL-10 (Donnelly et al., 1999), and transcriptional repressors (i.e., SOCS3). STAT3 acts by selectively inhibiting gene transcription of pro-inflammatory cytokines such as TNF- $\alpha$ and IL-12p40 in APC (Murray, 2005). Moreover, IL-10-induced SOCS3, which exerts negative regulatory effects on various cytokine genes by inhibiting STAT and JAK2 activation, is functioning in both T cells and APC (Mosser and Zhang, 2008).
In T cells, IL-10 also activates SOCS1, which negatively regulates IFN-induced gene transcription (i.e., IP-10 and ISG-4; Asadullah et al., 2003), whereas in APC, IL-10 selectively induces p50 nuclear translocation while blocks the translocation of the classical NF-kB heterodimer p65/p50 by inhibiting IKK activity (Wang et al., 1995; Clarke et al., 1998). Together the molecular mechanism of IL-10 to dampen activation of both T cells and APC plays a major part in regulating immune responses.

The broad immune-modulatory effects of IL-10 prompted investigators to perform clinical trials using human recombinant(r) IL-10 to treat inflammatory diseases. The earliest studies performed in patients with psoriasis were encouraging; IL-10 was tolerated well, and local subcutaneous administration of rIL-10 induced significant clinical benefits at the site of injection (Asadullah et al., 1998). In a subsequent study in patients with more severe forms of psoriasis the local delivery of rIL-10 to all lesions became a major challenge, thus systemic administration of rIL-10 was used but resulted in only temporary and local clinical improvement (Asadullah et al., 2001). In addition, in patients with Chron's disease, and rheumatoid arthritis, subcutaneous administration of rIL-10 was well tolerated but did not result in disease remission (Keystone et al., 1998; Schreiber et al., 2000). Unfortunately, 
patients from another Crohn's disease trial using daily subcutaneous administration for 28 days of high doses of rIL-10 had enhanced inflammatory $\mathrm{T}$ cell responses resulting in higher levels of TNF $\alpha$ and IFN $\gamma$ production (Tilg et al., 2002), suggesting that high levels of systemic IL-10 can have a immune-stimulatory effects. Taken together, these clinical trials indicate that IL-10 is most effective when delivered locally to the site of inflammation. In this scenario the use of IL-10-producing $\operatorname{Tr} 1$ cells, which produce high levels of IL-10 upon Ag-specific stimulation, represents an alternative approach to the delivery of IL-10 at the site of Ag-specific inflammation.

Type 1 regulatory $\mathrm{T}$ cells indeed require TCR activation by their cognate Ag to produce high amounts of IL-10 and to induce bystander tolerogenic effects. Allergen-specific immunotherapy (SIT) induces a significant increase of Ag-specific IL-10-producing Tr 1 cells and elevated levels of IL- 10 and TGF- $\beta$ in peripheral blood and allergic tissues in patients (Akkoc et al., 2011; Jutel and Akdis, 2011). The induction of Ag-specific $\operatorname{Tr} 1$ cells can lead to bystander suppression in patients after SIT. Two independent groups demonstrated that peptide-specific $\operatorname{Tr} 1$ cells induced after SIT could down-regulate an established inflammatory response driven by multiple T cell epitopes (Grindebacke et al., 2009; Yamanaka et al., 2009). These bystander effects, however, do not lead to systemic immuno-suppression, since tolerant patients with high frequency of $\operatorname{Tr} 1$ cells and patients adoptively transferred with $\operatorname{Tr} 1$ cells have normal immune responses to pathogens (Bacchetta et al., 2009; Serafini et al., 2009; Roncarolo et al., 2011; Bacchetta et al., submitted).

\section{CELL CONTACT-DEPENDENT MECHANISMS OF SUPPRESSION BY Tr1 CELLS}

Type 1 regulatory $\mathrm{T}$ cells express inhibitory receptors including CTLA-4 (Bacchetta et al., 2002; Akdis et al., 2004), PD-1 (Akdis et al., 2004), and ICOS (Haringer et al., 2009) that are known to modulate $\mathrm{T}$ cell functions. CTLA-4 is a negative regulator of T cell activation (Rudd et al., 2009) known to be expressed on FOXP3 $^{+} \mathrm{T}_{\text {reg }}$ (Takahashi et al., 2000). Akdis et al. demonstrated that allergen-specific Tr1 cells inhibit allergen-specific Th2 cells via CTLA-4 (Akdis et al., 2004; Meiler et al., 2008) and suggested that CTLA- 4 co-operates with IL-10 and TGF- $\beta$ in the suppression of allergic responses mediated by $\operatorname{Tr} 1$ cells. PD- 1 is a receptor that is critical for the regulation of $\mathrm{T}$ cell activation and function during immunity and tolerance. PD-1 interactions with its ligands PD-Ligand (L) 1 and PD-L2 inhibit T cell effector functions in an Ag-specific manner (reviewed in Fife and Pauken, 2011). It has been shown that neutralization of PD-1 partially inhibits Tr1-mediated suppression of allergen-specific T cells (Akdis et al., 2004; Meiler et al., 2008), suggesting that PD-1 plays a role in the suppression mediated by $\operatorname{Tr} 1$ cells (Figure 1B). Despite these results it remains to be defined to what extent $\operatorname{Tr} 1$ cells exploit cell-to-cell contact mechanisms to control immune responses.

\section{ROLE OF METABOLIC DISRUPTION IN Tr1 CELL-MEDIATED SUPPRESSION}

Like FOXP3 ${ }^{+} \mathrm{T}_{\text {reg }}$, Tr 1 cells can express the ectoenzymes CD39 and CD73 (Bergmann et al., 2007; Mandapathil et al., 2010) and are believed to use these enzymes to generate the immunosuppressive molecule adenosine. Bergmann et al. (2007) showed that in vitro generated IL-10-producing T cells in the presence of cyclooxygenase 2 (COX2)-expressing cells and immature DC express CD39 and CD73. Furthermore, Mandapathil et al. (2010) showed that adenosine generated by $\operatorname{Tr} 1$ cells suppresses proliferation and cytokine production of effector T cells upon binding with its receptor (Figure 1C). We have found that human $\operatorname{Tr} 1$ cell clones also express significantly higher levels of mRNA encoding for CD39 compared to Th0 cell clones (Gregori et al., unpublished data). These results suggest that metabolic disruption of conventional $\mathrm{T}$ cells might represent an additional mechanism used by $\operatorname{Tr} 1$ cells to mediate suppression.

\section{CYTOLYTIC ACTIVITY OF Tr1 CELLS}

Human $\operatorname{Tr} 1$ cells, depending on the mode of activation/generation, can express both GzA and $\mathrm{GzB}$ and selectively kill target cells (Grossman et al., 2004b; Kawamura et al., 2006; Efimova and Kelley, 2009; Czystowska et al., 2011; Magnani et al., 2011). We recently demonstrated that human $\operatorname{Tr} 1$ cells, generated in vitro and isolated ex vivo, express and release high levels of $\mathrm{GzB}$, and specifically lyse cells of myeloid origin, but not other APC or T and B lymphocytes (Magnani et al., 2011). Tr1-mediated cytotoxicity of myeloid APC is Ag-independent and requires recognition and activation via HLA class I molecules expressed on target cells (Figure 1D). This differs from NK cells, which kill target cells lacking HLA class I molecules. Specific killing of myeloid APC by $\operatorname{Tr} 1$ cells depends on the high expression levels of CD54, CD58, CD155, and CD112 on myeloid cells, which, upon interaction with their ligands on $\operatorname{Tr} 1$ cells, mediate stable $\operatorname{Tr} 1 /$ APC adhesion and $\operatorname{Tr} 1$ specific activation (Magnani et al., 2011). Killing of myeloid cells by $\operatorname{Tr} 1$ cells represents an additional indirect mechanism of suppression, which may contribute to bystander suppression. It is tempting to speculate that upon encounter with their cognate Ag $\operatorname{Tr} 1$ cells up-regulate GzB expression and kill myeloid cells in an Ag-non-specific manner. This indirect effect could result in a reduction of allo-reactive APC in the case of transplantation, or APC that present self-Ags in the case of autoimmune diseases, limiting priming and expansion of effector T cells.

\section{COMPARISON BETWEEN THE SUPPRESSIVE ACTIVITIES OF} FOXP3 $^{+} \mathrm{T}_{\text {reg }}$ AND Tr1 CELLS

FOXP $^{+}{ }^{+} \mathrm{T}_{\text {reg }}$ and $\operatorname{Tr} 1$ cells have distinct and shared mechanisms of suppression (see Table 2). The main distinction is that $\operatorname{Tr} 1$ cells suppress immune responses primarily via IL-10, whereas FOXP3 ${ }^{+}$ $\mathrm{T}_{\text {reg }}$ regulate effector $\mathrm{T}$ cells principally via $\mathrm{T}$ : $\mathrm{T}$ cell contact mediated mechanisms. TGF- $\beta$ is used by both cell subsets to modulate $\mathrm{T}$ cell responses, but $\operatorname{Tr} 1$ cells secrete TGF- $\beta$ upon activation via their TCR, while FOXP3 ${ }^{+} \mathrm{T}_{\text {reg }}$ express TGF- $\beta$ on the cell surface in a complex with latent associated peptide (LAP; Nakamura et al., 2001). More recently, it has been shown that GARP, an orphan toll-like receptor, is selectively expressed by activated FOXP3 ${ }^{+} \mathrm{T}_{\text {reg }}$ and is required for LAP expression (Stockis et al., 2009; Tran et al., 2009). GARP by interacting with LAP in activated FOXP3 ${ }^{+} \mathrm{T}_{\text {reg }}$ delivers LAP to their cell surface allowing suppression (Battaglia and Roncarolo, 2009; Stockis et al., 2009). It remains to be defined whether human $\operatorname{Tr} 1$ cells express LAP and GARP upon activation, and if they use LAP to suppress T cell responses. 
Induction of tolerogenic APC by FOXP $3^{+} \mathrm{T}_{\text {reg }}$ and $\mathrm{Tr} 1$ cells is a common mechanism of suppression. Since both $\mathrm{T}$ cell subsets express CTLA-4 it is likely that they induce similar tolerogenic signals in APC; however, it is still elusive whether the interaction between $\operatorname{Tr} 1$ cells and APC will lead to IDO expression as it has been demonstrated for FOXP3 ${ }^{+} \mathrm{T}_{\text {reg }}$ (Fallarino et al., 2003). Moreover, additional studies are needed to define if the interaction between CTLA- 4 on $\operatorname{Tr} 1$ cells and CD86 on APC synergizes with IL-10 to inhibit up-regulation of co-stimulatory molecules on APC.

Metabolic disruption of effector T cells by FOXP3 ${ }^{+} \mathrm{T}_{\text {reg }}$ and $\operatorname{Tr} 1$ cells represents an additional common mechanism of immune suppression. Both FOXP3 ${ }^{+} \mathrm{T}_{\text {reg }}$ and $\mathrm{Tr} 1$ cells express CD39 and CD73 and produce adenosine. On the contrary cytolysis mediated by FOXP3 ${ }^{+} \mathrm{T}_{\text {reg }}$ and $\mathrm{Tr} 1$ cells is distinct: FOXP3 ${ }^{+} \mathrm{T}_{\text {reg }}$ lyse a wide array of immune cells (Grossman et al., 2004b), whereas Tr1 cells specifically kill myeloid cells (Magnani et al., 2011).

\section{PRE-CLINICAL MODELS TO TEST SAFETY AND EFFICACY OF HUMAN Treg-BASED THERAPY}

Adoptive transfer of $\mathrm{T}_{\text {reg }}$ to restore or induce tolerance toward self-Ags or allo-Ags is an efficient means to prevent or cure several T cell mediated diseases, including GvHD, allograft rejection, autoimmunity, and chronic inflammatory diseases in preclinical mouse models (Bluestone et al., 2007; Roncarolo and Battaglia, 2007). To evaluate the efficacy of human FOXP3 ${ }^{+} \mathrm{T}_{\text {reg }}$ therapy in vivo humanized mouse models of xeno-GvHD and of allogeneic $\mathrm{T}$ cell responses have been developed. Kleinewietfeld et al. (2009) showed that adoptive transfer of human $\mathrm{CD}^{+}{ }^{+} \mathrm{CD} 27^{-} \mathrm{CD}^{-} \mathrm{d}^{-} \mathrm{FOXP}^{+} \mathrm{T}_{\text {reg }}$ is an effective means to prevent xeno-GvHD induced by human PBMC in $\mathrm{Rag}^{-1-} \mathrm{\gamma c}^{-1-}$ mice. Similarly, injection of in vitro expanded human FOXP3 ${ }^{+}$ $\mathrm{T}_{\text {reg }}$ with artificial APC expressing CD86 and CD64 in the presence of anti-CD3 mAbs, IL-2 and rapamycin could block xeno-GvHD induced by human PBMC in NOD/scid IL2R $\gamma \mathrm{c}^{\text {null }}$ mice (Golovina et al., 2008), while only partially delayed xeno-GvHD in NOD/scid mice (Hippen et al., 2011). In addition, preliminary results by our research group showed that human $\mathrm{T}$ cells engineered to stably over-express FOXP3 suppress xeno-GvHD in humanized NOD/scid mice (Passerini and Bacchetta, unpublished).
The efficacy of $\mathrm{T}_{\text {reg }}$-based cell therapy with human FOXP3 ${ }^{+}$ $\mathrm{T}_{\text {reg }}$ to suppress allogeneic $\mathrm{T}$ cell responses in vivo has been recently evaluated. In this study Sagoo et al. (2011) demonstrated in a humanized mouse allo-skin graft model that adoptive transfer of expanded alloAg-specific human $\mathrm{CD} 4^{+} \mathrm{CD} 25^{\text {high }} \mathrm{CD} 127^{\text {low/- }}$ $\mathrm{T}_{\mathrm{reg}}$, but not expanded polyclonal $\mathrm{CD} 4^{+} \mathrm{CD} 25^{\text {high }} \mathrm{CD} 127^{\text {low }}$ $\mathrm{T}_{\text {reg }}$, significantly improved protection of human skin damage. In addition, the group of $\mathrm{K}$. Wood demonstrated that transfer of in vitro expanded polyclonal $\mathrm{CD} 4^{+} \mathrm{CD} 25^{\text {high }} \mathrm{CD} 127^{\text {low }}-\mathrm{T}_{\text {reg }}$ (Nadig et al., 2010) or in vitro induced FOXP3 ${ }^{+} \mathrm{T}_{\text {reg }}$ (Feng et al., 2011) prevented ateroesclerosis in a humanized model. Taken together, adoptive transfer of human $\mathrm{FOXP}^{+}{ }^{+} \mathrm{T}_{\text {reg }}$ is a promising means to control $\mathrm{T}$ cell-mediated diseases in humanized mouse models suggesting that the efficacy of human $\mathrm{T}_{\text {reg }}$-based therapy may mirror the data garnered from the numerous pre-clinical mouse studies.

The effectiveness of Tr1-based cell therapy to control xenoGvHD is under investigation by our group. We have recently demonstrated in a humanized mouse model that human IL-10producing $\mathrm{CD}^{+} \operatorname{Tr} 1$ cells, generated by transducing $\mathrm{CD}^{+}{ }^{+} \mathrm{T}$ cells with a lentiviral vector encoding for IL-10, suppress xenoGvHD and promote survival when co-transferred with allogeneic PBMC (Andolfi and Fousteri, submitted). Additional studies are needed to define which are the mechanisms of in vivo suppression mediated by FOXP3 $\mathrm{T}_{\text {reg }}$ and $\mathrm{Tr} 1$ cells.

\section{CLINICAL TRIAL WITH $\mathrm{T}_{\text {reg }}$ CELLS}

Results obtained in pre-clinical studies and the evidence that $\mathrm{T}_{\text {reg }}$ are critically involved in promoting peripheral tolerance prompted investigators to use adoptive transfer of $\mathrm{T}_{\text {reg }}$ as a therapeutic. Proof-of-principle clinical trials in allogeneic HSCT demonstrated

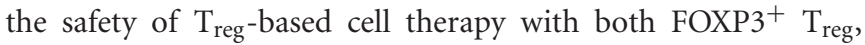
ex vivo isolated (Trzonkowski et al., 2009; Di Ianni et al., 2011; Edinger and Hoffmann, 2011) or in vitro expanded (Brunstein et al., 2010), and Tr1 cells (Bacchetta et al., 2009; Bacchetta, submitted). Furthermore, a phase I/II trial showed that cell therapy with $\operatorname{Tr} 1$ cell clones in patients displaying severe Crohn's disease is safe and does not lead to general immuno-suppression ${ }^{1}$. One of

\footnotetext{
${ }^{1}$ http://www.txcell.com
}

Table 3 | Clinical trials with $\mathrm{T}_{\text {reg }}$-based cell therapy.

\begin{tabular}{|c|c|c|c|c|c|}
\hline \multirow[t]{2}{*}{ Trial } & \multirow[t]{2}{*}{ Disease } & \multicolumn{3}{|c|}{ Methods of generation } & \multirow[t]{2}{*}{ Ag-specificity } \\
\hline & & In vitro induction & In vitro expansion & Ex vivo isolation & \\
\hline \multicolumn{6}{|l|}{ TR1 CELLS } \\
\hline Allo-specific (Bacchetta et al., 2009) & Allo-HSCT & Yes & No & No & Yes \\
\hline OVA-specific (http://www.txcell.com) & Crohn's disease & No & Yes & No & Yes \\
\hline \multicolumn{6}{|l|}{$\mathbf{T}_{\text {REG }}$ CELLS } \\
\hline CD25 high cells (Di lanni et al., 2011) & Allo-HSCT & No & No & Yes & No \\
\hline CD25 high cells (Brunstein et al., 2010) & Allo-HSCT & No & Yes & Yes & No \\
\hline CD25 high cells (Trzonkowski et al., 2009) & Allo-HSCT & No & Yes & Yes & No \\
\hline CD25 $5^{\text {high }}$ cells (Edinger and Hoffmann, 2011) & Allo-HSCT & No & No & Yes & No \\
\hline CD25+CD127 low/- cells (ClinicalTrials.gov & $\mathrm{T} 1 \mathrm{D}$ & No & Yes & Yes & No \\
\hline
\end{tabular}

Identifier: NCT01210664) 
the advantages of using $\operatorname{Tr} 1$ cells over FOXP $3^{+} \mathrm{T}_{\text {reg }}$, is that $\operatorname{Tr} 1$ cells are inducible ex vivo and, therefore, can be generated and expanded in vitro against the required Ag-specificity. Taken together, results from these clinical trials suggest that: (i) FOXP3 ${ }^{+} \mathrm{T}_{\text {reg }}$ may prevent GvHD without inhibiting prompt immune reconstitution in allo-HSCT (Brunstein et al., 2010; Di Ianni et al., 2011; Edinger and Hoffmann, 2011), (ii) allo-specific Tr1 cells promote faster immune reconstitution (Bacchetta et al., 2009; Bacchetta, submitted), (iii) infusion of autologous Ag-specific $\operatorname{Tr} 1$ cell clones in patients with Chron's disease has beneficial effects (see text footnote 1 ). Several open questions regarding $\mathrm{T}_{\text {reg }}$-based therapy in humans remain: how long do $\mathrm{T}_{\text {reg }}$ survive in vivo after transfer, what is their mechanism of suppression in vivo, and whether Agspecificity is required to induce long-term tolerance (see Table 3 ). Caution for Tr1-based cell therapy should be used considering the adverse effects of excessive levels of systemic IL-10 demonstrated in rIL-10 clinical trials (Tilg et al., 2002; Mosser and Zhang, 2008).

Future clinical trials planning to test the safety and efficacy

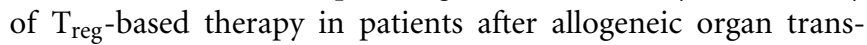
plant (THE ONE study) ${ }^{2}$ as well as in patients with autoimmune diseases, such as type 1 diabetes (ClinicalTrials.gov Identifier: NCT01210664) and rheumatoid arthritis (see text footnote 1) will define if $T_{\text {reg }}$ can suppress allograft rejection under the umbrella of immune suppression, and whether $\mathrm{T}_{\text {reg }}$ can suppress self-Ag specific $\mathrm{T}$ cell responses, and can regulate an ongoing

${ }^{2} \mathrm{http}: / /$ www.onestudy.org/

\section{REFERENCES}

Akdis, M., Verhagen, J., Taylor, A., Karamloo, F., Karagiannidis, C., Crameri, R., Thunberg, S., Deniz, G., Valenta, R., Fiebig, H., Kegel, C., Disch, R., Schmidt-Weber, C. B., Blaser, K., and Akdis, C. A. (2004). Immune responses in healthy and allergic individuals are characterized by a fine balance between allergen-specific $\mathrm{T}$ regulatory 1 and T helper 2 cells. J. Exp. Med. 199, 1567-1575.

Akkoc, T., Akdis, M., and Akdis, C. A. (2011). Update in the mechanisms of allergen-specific immunotheraphy. Allergy Asthma Immunol. Res. 3, 11-20.

Allan, S. E., Crome, S. Q., Crellin, N. K., Passerini, L., Steiner, T. S., Bacchetta, R., Roncarolo, M. G., and Levings, M. K. (2007). Activationinduced FOXP3 in human $\mathrm{T}$ effector cells does not suppress proliferation or cytokine production. Int. Immunol. 19, 345-354.

Apetoh, L., Quintana, F. J., Pot, C., Joller, N., Xiao, S., Kumar, D., Burns, E. J., Sherr, D. H., Weiner, H. L., and Kuchroo, V. K. (2010). The aryl hydrocarbon receptor interacts with c-Maf to promote the differentiation of type 1 regulatory $\mathrm{T}$ cells induced by IL-27. Nat. Immunol. 11 854-861.

Asadullah, K., Friedrich, M., Hanneken, S., Rohrbach, C., Audring, H., Vergopoulos, A., Ebeling, M., Docke, W. D., Volk, H. D., and Sterry, W. (2001). Effects of systemic interleukin-10 therapy on psoriatic skin lesions: histologic, immunohistologic, and molecular biology findings. J. Invest. Dermatol. 116, 721-727.

Asadullah, K., Sterry, W., Stephanek, K., Jasulaitis, D., Leupold, M., Audring, H., Volk, H. D., and Docke, W. D. (1998). IL-10 is a key cytokine in psoriasis. Proof of principle by IL-10 therapy: a new therapeutic approach. J. Clin. Invest. 101, 783-794.

Asadullah, K., Sterry, W., and Volk, H. D. (2003). Interleukin-10 therapy review of a new approach. Pharmacol. Rev. 55, 241-269.

Awasthi, A., Carrier, Y., Peron, J. P., Bettelli, E., Kamanaka, M., Flavell, R. A., Kuchroo, V. K., Oukka, M., and Weiner, H. L. (2007). A dominant function for interleukin 27 in generating interleukin 10-producing antiinflammatory T cells. Nat. Immunol. 8, 1380-1389.

Bacchetta, R., Bigler, M., Touraine, J. L., Parkman, R., Tovo, P. A., Abrams, J.,

immune response. Overall, these studies will define the efficacy

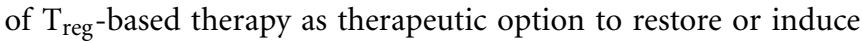
tolerance in $\mathrm{T}$ cell mediated diseases.

\section{CONCLUSION}

Since the discovery of $\operatorname{Tr} 1$ cells nearly two decades ago, research has firmly established their role in controlling immune homeostasis and modulating a wide variety of diseases. While a great deal of progress has been made in understanding the mechanisms of suppression by $\operatorname{Tr} 1$ cells, a number of questions still remain. First, a unique set of surface or intracellular marker(s) for $\operatorname{Tr} 1$ cells remains to be identified. Second, although it is well established that $\mathrm{FOXP}^{+} \mathrm{T}_{\text {reg }}$ and $\mathrm{Tr} 1$ cells are distinct populations sharing similar mechanism of suppression, additional research is needed to define what the relationship is between these $\mathrm{T}_{\text {reg }}$ subsets. Third, since there are several mechanisms of suppression used by $\operatorname{Tr} 1$ cells, it needs to be determined whether these mechanisms are operational in vivo and whether they are specific to a particular disease state. Answering these questions will not only bring us closer to understanding how $\operatorname{Tr} 1$ cells function, but also how to exploit or modulate their suppressive activity for targeted therapy against a wide variety of diseases.

\section{ACKNOWLEDGMENTS}

This work was supported by Telethon Foundation (Rome), the Italian Association for Cancer Research, project IG 10439 (AIRC), and KSG is funded by Juvenile Diabetes Research Foundation (JDRF).

De Waal Malefyt, R., De Vries, J. E., and Roncarolo, M. G. (1994). High levels of interleukin 10 production in vivo are associated with tolerance in SCID patients transplanted with HLA mismatched hematopoietic stem cells. J. Exp. Med. 179, 493-502.

Bacchetta, R., Gregori, S., Serafini, G., Sartirana, C., Schulz, U., Zino, E., Tomiuk, S., Jansen, U., Ponzoni, M., Paties, C. T., Fleischhauer, K., and Roncarolo, M. G. (2010). Molecular and functional characterization of alloantigenspecific anergic T-cells suitable for cell therapy. Haematologica 95, 2134-2143.

Bacchetta, R., Sartirana, C., Levings, M. K., Bordignon, C., Narula, S., and Roncarolo, M. G. (2002). Growth and expansion of human $\mathrm{T}$ regulatory type 1 cells are independent from TCR activation but require exogenous cytokines. Eur. J. Immunol. 32, 2237-2245.

Bacchetta, R., Sartirana, C., Lucarelli, B., Miqueu, P., Lupo Stanghellini, M. T., Greco, R., Velardi, A., Aversa, F., Martelli, M. F., Gregori, S., Zappone, E., Fleischhauer, K., Bernardi, M., Peccatori, J., Ciceri, F., and
Roncarolo, M. G. (2009). Inteleukin10 anergized donor $\mathrm{T}$ cell infusion improves immunereconstitution without severe graft-versushost disease after haploidentical hematopoietic stem cell transplantation. Blood ASH Annual Meeting Abstract 45.

Baron, U., Floess, S., Wieczorek, G., Baumann, K., Grutzkau, A., Dong, J., Thiel, A., Boeld, T. J., Hoffmann, P., Edinger, M., Turbachova, I., Hamann, A., Olek, S., and Huehn, J. (2007). DNA demethylation in the human FOXP3 locus discriminates regulatory $\mathrm{T}$ cells from activated FOXP3 $(+)$ conventional T cells. Eur. J. Immunol. 37, 2378-2389.

Barrat, F. J., Cua, D. J., Boonstra, A., Richards, D. F., Crain, C., Savelkoul, H. F., De Waal-Malefyt, R., Coffman, R. L., Hawrylowicz, C. M., and O'Garra, A. (2002). In vitro generation of interleukin 10-producing regulatory $\mathrm{CD} 4(+) \mathrm{T}$ cells is induced by immunosuppressive drugs and inhibited by $\mathrm{T}$ helper type 1 (Th1)and Th2-inducing cytokines. J. Exp. Med. 195, 603-616.

Battaglia, M., and Roncarolo, M. G. (2009). The Tregs' world according to GARP. Eur. J. Immunol. 39, 3296-3300. 
Bergmann, C., Strauss, L., Zeidler, R., Lang, S., and Whiteside, T. L. (2007). Expansion and characteristics of human $\mathrm{T}$ regulatory type 1 cells in co-cultures simulating tumor microenvironment. Cancer Immunol. Immunother. 56, 1429-1442.

Bluestone, J. A., Thomson, A. W., Shevach, E. M., and Weiner, H. L. (2007). What does the future hold for cell-based tolerogenic therapy? Nat. Rev. Immunol. 7, 650-654.

Boisvert, M., Chetoui, N., Gendron, S., and Aoudjit, F. (2010). Alpha2beta1 integrin is the major collagenbinding integrin expressed on human Th17 cells. Eur. J. Immunol. 40, 2710-2719.

Bopp, T., Becker, C., Klein, M., KleinHessling, S., Palmetshofer, A., Serfling, E., Heib, V., Becker, M., Kubach, J., Schmitt, S., Stoll, S., Schild, H., Staege, M. S., Stassen, M., Jonuleit, H., and Schmitt, E. (2007). Cyclic adenosine monophosphate is a key component of regulatory $\mathrm{T}$ cell-mediated suppression. J. Exp. Med. 204, 1303-1310.

Borsellino, G., Kleinewietfeld, M., Di Mitri, D., Sternjak, A., Diamantini, A., Giometto, R., Hopner, S., Centonze, D., Bernardi, G., Dell'Acqua, M. L., Rossini, P. M., Battistini, L., Rotzschke, O., and Falk, K. (2007). Expression of ectonucleotidase CD39 by Foxp3+ Treg cells: hydrolysis of extracellular ATP and immune suppression. Blood 110, 1225-1232.

Boussiotis, V. A., Tsai, E. Y., Yunis, E. J., Thim, S., Delgado, J. C., Dascher, C. C., Berezovskaya, A., Rousset, D., Reynes, J. M., and Goldfeld, A. E. (2000). IL-10-producing T cells suppress immune responses in anergic tuberculosis patients. J. Clin. Invest. 105, 1317-1325.

Brunstein, C. G., Miller, J. S., Cao, Q., Mckenna, D. H., Hippen, K. L., Curtsinger, J., Defor, T., Levine, B. L., June, C. H., Rubinstein, P., Mcglave, P. B., Blazar, B. R., and Wagner, J. E. (2010). Infusion of ex vivo expanded $\mathrm{T}$ regulatory cells in adults transplanted with umbilical cord blood: safety profile and detection kinetics. Blood 117, 1061-1070.

Camisaschi, C., Casati, C., Rini, F., Perego, M., De Filippo, A., Triebel, F., Parmiani, G., Belli, F., Rivoltini, L., and Castelli, C. (2010). LAG3 expression defines a subset of CD4(+)CD25(high)Foxp3(+) regulatory $\mathrm{T}$ cells that are expanded at tumor sites. J. Immunol. 184, 6545-6551.
Cavani, A., Nasorri, F., Prezzi, C., Sebastiani, S., Albanesi, C., and Girolomoni, G. (2000). Human CD4+ T lymphocytes with remarkable regulatory functions on dendritic cells and nickel-specific Th1 immune responses. J. Invest. Dermatol. 114, 295-302.

Chang, H. D., Helbig, C., Tykocinski, L., Kreher, S., Koeck, J., Niesner, U., and Radbruch, A. (2007). Expression of IL-10 in Th memory lymphocytes is conditional on IL-12 or IL-4, unless the IL-10 gene is imprinted by GATA-3. Eur. J. Immunol. 37, 807-817.

Charbonnier, L. M., Van Duivenvoorde, L. M., Apparailly, F., Cantos, C., Han, W. G., Noel, D., Duperray, C., Huizinga, T. W., Toes, R. E., Jorgensen, C., and Louis-Plence, P. (2006). Immature dendritic cells suppress collagen-induced arthritis by in vivo expansion of CD49b+ regulatory T cells. J. Immunol. 177, 3806-3813.

Chaturvedi, V., Collison, L. W., Guy, C. S., Workman, C. J., and Vignali, D. A. (2011). Cutting edge: human regulatory T cells require IL- 35 to mediate suppression and infectious tolerance. J. Immunol. 186, 6661-6666.

Clarke, C. J., Hales, A., Hunt, A., and Foxwell, B. M. (1998). IL-10mediated suppression of TNF-alpha production is independent of its ability to inhibit NF kappa B activity. Eur. J. Immunol. 28, 1719-1726.

Crotty, S. (2011). Follicular helper CD4 T cells (TFH). Annu. Rev. Immunol. 29, 621-663.

Cullen, S. P., and Martin, S. J. (2008). Mechanisms of granuledependent killing. Cell Death Differ. 15, 251-262.

Czystowska, M., Strauss, L., Bergmann, C., Szajnik, M., Rabinowich, H., and Whiteside, T. L. (2011). Reciprocal granzyme/perforin-mediated death of human regulatory and responder $\mathrm{T}$ cells is regulated by interleukin-2 (IL-2). J. Mol. Med. 88, 577-588.

de Beaucoudrey, L., Puel, A., FilipeSantos, O., Cobat, A., Ghandil, P., Chrabieh, M., Feinberg, J., Von Bernuth, H., Samarina, A., Janniere, L., Fieschi, C., Stephan, J. L., Boileau, C., Lyonnet, S., Jondeau, G., Cormier-Daire, V., Le Merrer, M., Hoarau, C., Lebranchu, Y., Lortholary, O., Chandesris, M. O., Tron, F., Gambineri, E., Bianchi, L., Rodriguez-Gallego, C., Zitnik, S. E., Vasconcelos, J., Guedes, M., Vitor, A. B., Marodi, L., Chapel, H., Reid, B., Roifman, C., Nadal, D., Reichenbach, J., Caragol, I., Garty, B. Z., Dogu, F., Camcioglu, Y., Gulle, S., Sanal,
O., Fischer, A., Abel, L., Stockinger, B., Picard, C., and Casanova, J. L. (2008). Mutations in STAT3 and IL12RB1 impair the development of human IL-17-producing T cells. J. Exp. Med. 205, 1543-1550.

de la Rosa, M., Rutz, S., Dorninger, H., and Scheffold, A. (2004). Interleukin-2 is essential for CD4+CD25+ regulatory $\mathrm{T}$ cell function. Eur. J. Immunol. 34, 2480-2488.

de Waal Malefyt, R., Haanen, J., Spits, H., Roncarolo, M. G., Te Velde, A. Figdor, C., Johnson, K., Kastelein, R., Yssel, H., and De Vries, J. E. (1991). Interleukin 10 (IL-10) and viral IL10 strongly reduce antigen-specific human $\mathrm{T}$ cell proliferation by diminishing the antigen-presenting capacity of monocytes via downregulation of class II major histocompatibility complex expression. J. Exp. Med. 174, 915-924.

de Waal Malefyt, R., Yssel, H., and De Vries, J. E. (1993). Direct effects of IL-10 on subsets of human CD4+ T cell clones and resting $\mathrm{T}$ cells. Specific inhibition of IL-2 production and proliferation. J. Immunol. 150, 4754-4765.

Deaglio, S., Dwyer, K. M., Gao, W., Friedman, D., Usheva, A., Erat, A., Chen, J. F., Enjyoji, K., Linden, J. Oukka, M., Kuchroo, V. K., Strom, T. B., and Robson, S. C. (2007). Adenosine generation catalyzed by $\mathrm{CD} 39$ and CD73 expressed on regulatory $\mathrm{T}$ cells mediates immune suppression. J. Exp. Med. 204, 1257-1265.

Del Prete, G., De Carli, M.,Almerigogna, F., Giudizi, M. G., Biagiotti, R., and Romagnani, S. (1993). Human IL10 is produced by both type 1 helper (Th1) and type 2 helper (Th2) T cell clones and inhibits their antigen-specific proliferation and cytokine production. J. Immunol. 150, 353-360.

Di Ianni, M., Falzetti, F., Carotti, A., Terenzi, A., Castellino, F., Bonifacio, E., Del Papa, B., Zei, T. Ostini, R. I., Cecchini, D., Aloisi, T., Perruccio, K., Ruggeri, L., Balucani, C., Pierini, A., Sportoletti, P., Aristei, C., Falini, B., Reisner, Y., Velardi, A., Aversa, F., and Martelli, M. F. (2011). Tregs prevent GVHD and promote immune reconstitution in HLA-haploidentical transplantation. Blood 117, 3921-3928.

Donnelly, R. P., Dickensheets, H., and Finbloom, D. S. (1999). The interleukin-10 signal transduction pathway and regulation of gene expression in mononuclear phagocytes. J. Interferon Cytokine Res. 19, 563-573.
Edinger, M., and Hoffmann, P. (2011). Regulatory $\mathrm{T}$ cells in stem cell transplantation: strategies and first clinical experiences. Curr. Opin. Immunol. 23, 679-684.

Efimova, O. V., and Kelley, T. W. (2009). Induction of granzyme B expression in T-cell receptor/CD28-stimulated human regulatory $\mathrm{T}$ cells is suppressed by inhibitors of the PI3KmTOR pathway. BMC Immunol. 10, 59. doi:10.1186/1471-2172-10-59

Fallarino, F., Grohmann, U., Hwang, K. W., Orabona, C., Vacca, C., Bianchi, R., Belladonna, M. L., Fioretti, M. C., Alegre, M. L., and Puccetti, P. (2003). Modulation of tryptophan catabolism by regulatory T cells. Nat. Immunol. 4, 1206-1212.

Fantini, M. C., Becker, C., Monteleone, G., Pallone, F., Galle, P. R., and Neurath, M. F. (2004). Cutting edge: TGF-beta induces a regulatory phenotype in $\mathrm{CD} 4+\mathrm{CD} 25-\mathrm{T}$ cells through Foxp3 induction and downregulation of Smad7. J. Immunol. 172, 5149-5153.

Feng, G., Nadig, S. N., Backdahl, L., Beck, S., Francis, R. S., Schiopu, A., Whatcott, A., Wood, K. J., and Bushell, A. (2011). Functional regulatory $\mathrm{T}$ cells produced by inhibiting cyclic nucleotide phosphodiesterase type 3 prevent allograft rejection. Sci. Transl. Med. 3, 83ra40.

Fife, B. T., and Pauken, K. E. (2011). The role of the PD-1 pathway in autoimmunity and peripheral tolerance. Ann. N. Y. Acad. Sci. 1217, 45-59.

Fiorentino, D. F., Zlotnik, A., Mosmann, T. R., Howard, M., and O'Garra, A. (1991a). IL-10 inhibits cytokine production by activated macrophages. J. Immunol. 147, 3815-3822.

Fiorentino, D. F., Zlotnik, A., Vieira, P., Mosmann, T. R., Howard, M., Moore, K. W., and O'Garra, A. (1991b). IL-10 acts on the antigenpresenting cell to inhibit cytokine production by Th1 cells. J. Immunol. 146, 3444-3451.

Fitzgerald, D. C., Zhang, G. X., ElBehi, M., Fonseca-Kelly, Z., Li, H., Yu, S., Saris, C. J., Gran, B., Ciric, B., and Rostami, A. (2007). Suppression of autoimmune inflammation of the central nervous system by interleukin 10 secreted by interleukin 27-stimulated T cells. Nat. Immunol. 8, 1372-1379.

Gerosa, F., Paganin, C., Peritt, D., Paiola, F., Scupoli, M. T., Aste-Amezaga, M., Frank, I., and Trinchieri, G. (1996). Interleukin-12 primes human CD4 and CD8 T cell clones for high production of both interferon-gamma 
and interleukin-10. J. Exp. Med. 183, 2559-2569.

Gianfrani, C., Levings, M. K., Sartirana, C., Mazzarella, G., Barba, G., Zanzi, D., Camarca, A., Iaquinto, G., Giardullo, N., Auricchio, S., Troncone, R., and Roncarolo, M. G. (2006). Gliadin-specific type 1 regulatory $\mathrm{T}$ cells from the intestinal mucosa of treated celiac patients inhibit pathogenic T cells. J. Immunol. 177, 4178-4186.

Go, N. F., Castle, B. E., Barrett, R., Kastelein, R., Dang, W., Mosmann, T. R., Moore, K. W., and Howard, M. (1990). Interleukin 10, a novel B cell stimulatory factor: unresponsiveness of $\mathrm{X}$ chromosome-linked immunodeficiency B cells. J. Exp. Med. 172, 1625-1631.

Golovina, T. N., Mikheeva, T., Suhoski, M. M., Aqui, N. A., Tai, V. C., Shan, X., Liu, R., Balcarcel, R. R., Fisher, N., Levine, B. L., Carroll, R. G., Warner, N., Blazar, B. R., June, C. H., and Riley, J. L. (2008). CD28 costimulation is essential for human $\mathrm{T}$ regulatory expansion and function. $J$. Immunol. 181, 2855-2868.

Gorelik, L., Constant, S., and Flavell, R. A. (2002). Mechanism of transforming growth factor beta-induced inhibition of T helper type 1 differentiation. J. Exp. Med. 195, 1499-1505.

Gorelik, L., and Flavell, R. A. (2002). Transforming growth factor-beta in T-cell biology. Nat. Rev. Immunol. 2, 46-53.

Granelli-Piperno, A., Golebiowska, A., Trumpfheller, C., Siegal, F. P., and Steinman, R. M. (2004). HIV1 -infected monocyte-derived dendritic cells do not undergo maturation but can elicit IL-10 production and T cell regulation. Proc. Natl. Acad. Sci. U.S.A. 101, 7669-7674.

Gregori, S. (2011). Dendritic cells in networks of immunological tolerance. Tissue Antigens 77, 89-99.

Gregori, S., Tomasoni, D., Pacciani, V., Scirpoli, M., Battaglia, M., Magnani, C. F., Hauben, E., and Roncarolo, M. G. (2010). Differentiation of type $1 \mathrm{~T}$ regulatory cells $(\operatorname{Tr} 1)$ by tolerogenic $\mathrm{DC}-10$ requires the IL-10-dependent ILT4/HLA-G pathway. Blood 116, 935-944.

Grindebacke, H., Larsson, P., Wing, K., Rak, S., and Rudin, A. (2009). Specific immunotherapy to birch allergen does not enhance suppression of Th2 cells by CD4(+)CD25(+) regulatory T cells during pollen season. J. Clin. Immunol. 29, 752-760.

Grossman, W. J., Verbsky, J. W., Barchet, W., Colonna, M., Atkinson, J. P., and Ley, T. J. (2004a). Human T regulatory cells can use the perforin pathway to cause autologous target cell death. Immunity 21, 589-601.

Grossman, W. J., Verbsky, J. W., Tollefsen, B. L., Kemper, C., Atkinson, J. P., and Ley, T. J. (2004b). Differential expression of granzymes A and $\mathrm{B}$ in human cytotoxic lymphocyte subsets and T regulatory cells. Blood 104, 2840-2848.

Groux, H., Bigler, M., De Vries, J. E., and Roncarolo, M. G. (1996). Interleukin-10 induces a long-term antigen-specific anergic state in human CD4+ T cells. J. Exp. Med. 184, 19-29.

Groux, H., Bigler, M., De Vries, J. E., and Roncarolo, M. G. (1998). Inhibitory and stimulatory effects of IL-10 on human CD8+ T cells. J. Immunol. 160, 3188-3193.

Groux, H., O'Garra, A., Bigler, M., Rouleau, M., Antonenko, S., De Vries, J. E., and Roncarolo, M. G. (1997). A CD4+ T-cell subset inhibits antigen-specific $\mathrm{T}$ cell responses and prevents colitis. Nature 389, 737-742.

Ha, S. J., West, E. E., Araki, K., Smith, K. A., and Ahmed, R. (2008). Manipulating both the inhibitory and stimulatory immune system towards the success of therapeutic vaccination against chronic viral infections. Immunol. Rev. 223, 317-333.

Haringer, B., Lozza, L., Steckel, B., and Geginat, J. (2009). Identification and characterization of IL10/IFN-gamma-producing effectorlike $\mathrm{T}$ cells with regulatory function in human blood. J. Exp. Med. 206, 1009-1017.

Hippen, K. L., Merkel, S. C., Schirm, D. K., Sieben, C. M., Sumstad, D., Kadidlo, D. M., Mckenna, D. H., Bromberg, J. S., Levine, B. L., Riley, J. L., June, C. H., Scheinberg, P., Douek, D. C., Miller, J. S., Wagner, J. E., and Blazar, B. R. (2011). Massive ex vivo expansion of human natural regulatory $\mathrm{T}$ cells $(\mathrm{T}(\mathrm{regs}))$ with minimal loss of in vivo functional activity. Sci. Transl. Med. 3, 83ra41.

Hiramatsu, Y., Suto, A., Kashiwakuma, D., Kanari, H., Kagami, S., Ikeda, K., Hirose, K., Watanabe, N., Grusby, M. J., Iwamoto, I., and Nakajima, H. (2010). c-Maf activates the promoter and enhancer of the IL-21 gene, and TGF-beta inhibits c-Mafinduced IL-21 production in CD4+ T cells. J. Leukoc. Biol. 87, 703-712.

Hoffmann, P., Eder, R., Boeld, T. J., Doser, K., Piseshka, B., Andreesen, R., and Edinger, M. (2006). Only the CD45RA+ subpopulation of $\mathrm{CD} 4+\mathrm{CD} 25$ high $\mathrm{T}$ cells gives rise to homogeneous regulatory $\mathrm{T}$-cell lines upon in vitro expansion. Blood 108, 4260-4267.

Hori, S., Nomura, T., and Sakaguchi, S. (2003). Control of regulatory $\mathrm{T}$ cell development by the transcription factor Foxp3. Science 299, 1057-1061.

Horwitz, D. A., Zheng, S. G., Wang, J., and Gray, J. D. (2008). Critical role of IL-2 and TGF-beta in generation, function and stabilization of Foxp3+CD4+ Treg. Eur. J. Immunol. 38, 912-915.

Ito, T., Hanabuchi, S., Wang, Y. H., Park, W. R., Arima, K., Bover, L., Qin, F. X., Gilliet, M., and Liu, Y. J. (2008). Two functional subsets of FOXP3 + regulatory $\mathrm{T}$ cells in human thymus and periphery. Immunity 28, 870-880.

Jiang, H., Canfield, S. M., Gallagher, M. P., Jiang, H. H., Jiang, Y., Zheng, Z., and Chess, L. (2010). HLAE-restricted regulatory CD8(+) $\mathrm{T}$ cells are involved in development and control of human autoimmune type 1 diabetes. J. Clin. Invest. 120, 3641-3650.

Jutel, M., and Akdis, C. A. (2011). Immunological mechanisms of allergen-specific immunotherapy. Allergy 66, 725-732.

Kawamura, K., Kadowaki, N., Kitawaki, T., and Uchiyama, T. (2006). Virus-stimulated plasmacytoid dendritic cells induce CD4+ cytotoxic regulatory T cells. Blood 107, 1031-1038.

Keystone, E., Wherry, J., and Grint, P. (1998). IL-10 as a therapeutic strategy in the treatment of rheumatoid arthritis. Rheum. Dis. Clin. North Am. 24, 629-639.

Khattri, R., Cox, T., Yasayko, S. A. and Ramsdell, F. (2003). An essential role for Scurfin in CD4+CD25+ T regulatory cells. Nat. Immunol. 4 337-342.

Kleinewietfeld, M., Starke, M., Di Mitri, D., Borsellino, G., Battistini, L., Rotzschke, O., and Falk, K. (2009). CD49d provides access to "untouched" human Foxp3+ Treg free of contaminating effector cells. Blood 113, 827-836.

Levings, M. K., Gregori, S., Tresoldi, E., Cazzaniga, S., Bonini, C., and Roncarolo, M. G. (2005). Differentiation of $\operatorname{Tr} 1$ cells by immature dendritic cells requires IL-10 but not CD25+CD4+ Tr cells. Blood 105, 1162-1169.

Levings, M. K., Sangregorio, R., Galbiati, F., Squadrone, S., De Waal Malefyt, R., and Roncarolo, M. G. (2001a). IFN-alpha and IL-10 induce the differentiation of human type $1 \mathrm{~T}$ regulatory cells. J. Immunol. 166, 5530-5539.
Levings, M. K., Sangregorio, R., and Roncarolo, M. G. (2001b). Human cd25(+)cd4(+) t regulatory cells suppress naive and memory $\mathrm{T}$ cell proliferation and can be expanded in vitro without loss of function. $J$. Exp. Med. 193, 1295-1302.

Liang, B., Workman, C., Lee, J., Chew, C., Dale, B. M., Colonna, L., Flores, M. Li, N., Schweighoffer, E., Greenberg, S., Tybulewicz, V., Vignali, D., and Clynes, R. (2008). Regulatory T cells inhibit dendritic cells by lymphocyte activation gene- 3 engagement of MHC class II. J. Immunol. 180, 5916-5926.

Liu, W., Putnam, A. L., Xu-Yu, Z., Szot, G. L., Lee, M. R., Zhu, S., Gottlieb, P. A., Kapranov, P., Gingeras, T. R., Fazekas De St Groth, B., Clayberger, C., Soper, D. M., Ziegler, S. F., and Bluestone, J. A. (2006). CD127 expression inversely correlates with FoxP3 and suppressive function of human CD4+ T reg cells. J. Exp. Med. 203, 1701-1711.

Liu, Z., Tugulea, S., Cortesini, R., and Suciu-Foca, N. (1998). Specific suppression of $\mathrm{T}$ helper alloreactivity by allo-MHC class I-restricted CD8+CD28- T cells. Int. Immunol. 10, 775-783.

Lu, L., Zhou, X., Wang, J., Zheng, S. G., and Horwitz, D. A. (2010). Characterization of protective human CD4CD25 FOXP3 regulatory T cells generated with IL-2, TGF-beta and retinoic acid. PLOS ONE 5, e15150. doi:10.1371/journal.pone.0015150

Magnani, C. F., Alberigo, G., Bacchetta, R., Serafini, G., Andreani, M., Roncarolo, M. G., and Gregori, S. (2011). Killing of myeloid APCs via HLA class I, CD2 and CD226 defines a novel mechanism of suppression by human $\operatorname{Tr} 1$ cells. Eur. J. Immunol. 41, 1652-1662.

Manavalan, J. S., Rossi, P. C., Vlad, G., Piazza, F., Yarilina, A., Cortesini, R., Mancini, D., and Suciu-Foca, N. (2003). High expression of ILT3 and ILT4 is a general feature of tolerogenic dendritic cells. Transpl. Immunol. 11, 245-258.

Mandapathil, M., Szczepanski, M. J., Szajnik, M., Ren, J., Jackson, E. K., Johnson, J. T., Gorelik, E., Lang, S., and Whiteside, T. L. (2010). Adenosine and prostaglandin E2 cooperate in the suppression of immune responses mediated by adaptive regulatory T cells. J. Biol. Chem. 285, 27571-27580.

McGeachy, M. J., Bak-Jensen, K. S., Chen, Y., Tato, C. M., Blumenschein, W., Mcclanahan, T., and Cua, D. J. (2007). TGF-beta and IL-6 drive the production of IL-17 and IL-10 by 
$\mathrm{T}$ cells and restrain $\mathrm{T}(\mathrm{H})-17$ cellmediated pathology. Nat. Immunol. 8, 1390-1397.

McGuirk, P., Mccann, C., and Mills, K. H. (2002). Pathogen-specific T regulatory 1 cells induced in the respiratory tract by a bacterial molecule that stimulates interleukin 10 production by dendritic cells: a novel strategy for evasion of protective $T$ helper type 1 responses by Bordetella pertussis. J. Exp. Med. 195, 221-231.

Meiler, F., Zumkehr, J., Klunker, S., Ruckert, B., Akdis, C. A., and Akdis, M. (2008). In vivo switch to IL-10secreting $\mathrm{T}$ regulatory cells in high dose allergen exposure. J. Exp. Med. 205, 2887-2898.

Miller, A., Lider, O., Roberts, A. B., Sporn, M. B., and Weiner, H. L. (1992). Suppressor T cells generated by oral tolerization to myelin basic protein suppress both in vitro and in vivo immune responses by the release of transforming growth factor beta after antigen-specific triggering. Proc. Natl. Acad. Sci. U.S.A. $89,421-425$.

Miyara, M., Yoshioka, Y., Kitoh, A., Shima, T., Wing, K., Niwa, A., Parizot, C., Taflin, C., Heike, T., Valeyre, D., Mathian, A., Nakahata, T., Yamaguchi, T., Nomura, T., Ono, M., Amoura, Z., Gorochov, G., and Sakaguchi, S. (2009). Functional delineation and differentiation dynamics of human CD4+ T cells expressing the FoxP3 transcription factor. Immunity 30, 899-911.

Moreau, P., Adrian-Cabestre, F., Menier, C., Guiard, V., Gourand, L., Dausset, J., Carosella, E. D., and Paul, P. (1999). IL-10 selectively induces HLA-G expression in human trophoblasts and monocytes. Int. Immunol. 11, 803-811.

Morelli, A. E., and Thomson, A. W. (2007). Tolerogenic dendritic cells and the quest for transplant tolerance. Nat. Rev. Immunol. 7, 610-621.

Mosser, D. M., and Zhang, X. (2008). Interleukin-10: new perspectives on an old cytokine. Immunol. Rev. 226, 205-218.

Munn, D. H., Sharma, M. D., and Mellor, A. L. (2004). Ligation of B7-1/B72 by human $\mathrm{CD} 4+\mathrm{T}$ cells triggers indoleamine 2,3-dioxygenase activity in dendritic cells. J. Immunol. 172 , 4100-4110.

Murray, P. J. (2005). The primary mechanism of the IL-10-regulated antiinflammatory response is to selectively inhibit transcription. Proc. Natl. Acad. Sci. U.S.A. 102, 8686-8691.

Murugaiyan, G., Mittal, A., LopezDiego, R., Maier, L. M., Anderson, D. E., and Weiner, H. L. (2009). IL-27 is a key regulator of IL-10 and IL-17 production by human $\mathrm{CD} 4+\mathrm{T}$ cells. J. Immunol. 183, 2435-2443.

Nadig, S. N., Wieckiewicz, J., Wu, D. C., Warnecke, G., Zhang, W., Luo, S., Schiopu, A., Taggart, D. P., and Wood, K. J. (2010). In vivo prevention of transplant arteriosclerosis by ex vivo-expanded human regulatory T cells. Nat. Med. 16, 809-813.

Nakamura, K., Kitani, A., and Strober, W. (2001). Cell contactdependent immunosuppression by $\mathrm{CD} 4(+) \mathrm{CD} 25(+)$ regulatory $\mathrm{T}$ cells is mediated by cell surface-bound transforming growth factor beta. $J$. Exp. Med. 194, 629-644.

Oberle, N., Eberhardt, N., Falk, C. S., Krammer, P. H., and SuriPayer, E. (2007). Rapid suppression of cytokine transcription in human $\mathrm{CD} 4+\mathrm{CD} 25 \mathrm{~T}$ cells by CD4+Foxp3+ regulatory $\mathrm{T}$ cells: independence of IL-2 consumption, TGF-beta, and various inhibitors of TCR signaling. J. Immunol. 179, 3578-3587.

Okamura, T., Fujio, K., Shibuya, M., Sumitomo, S., Shoda, H., Sakaguchi, S., and Yamamoto, K. (2009). CD4+CD25-LAG3+ regulatory $\mathrm{T}$ cells controlled by the transcription factor Egr-2. Proc. Natl. Acad. Sci. U.S.A. 106, 13974-13979.

Park, H., Li, Z., Yang, X. O., Chang, S. H., Nurieva, R., Wang, Y. H., Wang, Y., Hood, L., Zhu, Z., Tian, Q., and Dong, C. (2005). A distinct lineage of $\mathrm{CD} 4 \mathrm{~T}$ cells regulates tissue inflammation by producing interleukin 17 . Nat. Immunol. 6, 1133-1141.

Passerini, L., Allan, S. E., Battaglia, M., Di Nunzio, S., Alstad, A. N., Levings, M. K., Roncarolo, M. G., and Bacchetta, R. (2008). STAT5-signaling cytokines regulate the expression of FOXP3 in CD4+CD25+ regulatory $\mathrm{T}$ cells and $\mathrm{CD} 4+\mathrm{CD} 25-$ effector T cells. Int. Immunol. 20, 421-431.

Passerini, L., Di Nunzio, S., Gregori, S., Gambineri, E., Cecconi, M., Seidel, M. G., Cazzola, G., Perroni, L., Tommasini, A., Vignola, S., Guidi, L., Roncarolo, M. G., and Bacchetta, R. (2011). Functional type 1 regulatory $\mathrm{T}$ cells develop regardless of FOXP3 mutations in patients with IPEX syndrome. Eur. J. Immunol. 41, 1120-1131.

Pot, C., Jin, H., Awasthi, A., Liu, S. M., Lai, C. Y., Madan, R., Sharpe, A. H., Karp, C. L., Miaw, S. C., Ho, I. C., and Kuchroo, V. K. (2009). Cutting edge: IL-27 induces the transcription factor c-Maf, cytokine IL21 , and the costimulatory receptor ICOS that coordinately act together to promote differentiation of IL-10producing Tr1 cells. J. Immunol. 183, 797-801.

Rahmoun, M., Foussat, A., Groux, H., Pene, J., Yssel, H., and Chanez, P. (2006). Enhanced frequency of CD18- and CD49b-expressing $\mathrm{T}$ cells in peripheral blood of asthmatic patients correlates with disease severity. Int. Arch. Allergy Immunol. 140, 139-149.

Raimondi, G., Shufesky, W. J., Tokita, D. Morelli, A. E., and Thomson, A. W. (2006). Regulated compartmentalization of programmed cell death-1 discriminates $\mathrm{CD} 4+\mathrm{CD} 25+$ resting regulatory $\mathrm{T}$ cells from activated $\mathrm{T}$ cells. J. Immunol. 176, 2808-2816.

Rani, A., Afzali, B., Kelly, A., TewoldeBerhan, L., Hackett, M., Kanhere, A. S., Pedroza-Pacheco, I., Bowen, H., Jurcevic, S., Jenner, R. G., Cousins, D. J., Ragheb, J. A., Lavender, P., and John, S. (2011). IL-2 regulates expression of C-MAF in human CD4 T Cells. J. Immunol. 187, 3721-3729.

Roncarolo, M. G., and Battaglia, M. (2007). Regulatory T-cell immunotherapy for tolerance to self antigens and alloantigens in humans. Nat. Rev. Immunol. 7, 585-598.

Roncarolo, M. G., Gregori, S., Battaglia, M., Bacchetta, R., Fleischhauer, K., and Levings, M. K. (2006). Interleukin-10-secreting type 1 regulatory $\mathrm{T}$ cells in rodents and humans. Immunol. Rev. 212, 28-50.

Roncarolo, M. G., Gregori, S., Lucarelli, B., Ciceri, F., and Bacchetta, R. (2011). Clinical tolerance in allogeneic hematopoietic stem cell transplantation. Immunol. Rev. 241, 145-163.

Roncarolo, M. G., and Levings, M. K. (2000). The role of different subsets of $\mathrm{T}$ regulatory cells in controlling autoimmunity. Curr. Opin. Immunol. 12, 676-683.

Roncarolo, M. G., Yssel, H., Touraine, J. L., Betuel, H., De Vries, J. E., and Spits, H. (1988). Autoreactive $\mathrm{T}$ cell clones specific for class I and class II HLA antigens isolated from a human chimera. J. Exp. Med. 167, 1523-1534.

Rudd, C. E., Taylor, A., and Schneider, H. (2009). CD28 and CTLA-4 coreceptor expression and signal transduction. Immunol. Rev. 229, 12-26.

Sabat, R. (2010). IL-10 family of cytokines. Cytokine Growth Factor Rev. 21, 315-324.

Sagoo, P., Ali, N., Garg, G., Nestle, F. O., Lechler, R. I., and Lombardi, G. (2011). Human regulatory $\mathrm{T}$ cells with alloantigen specificity are more potent inhibitors of alloimmune skin graft damage than polyclonal regulatory T cells. Sci. Transl. Med. $3,83 \mathrm{ra} 42$.

Sakaguchi, S. (2005). Naturally arising Foxp3-expressing CD25+CD4+ regulatory $\mathrm{T}$ cells in immunological tolerance to self and non-self. Nat. Immunol. 6, 345-352.

Sakaguchi, S., Sakaguchi, N., Asano, M., Itoh, M., and Toda, M. (1995). Immunologic self-tolerance maintained by activated $\mathrm{T}$ cells expressing IL-2 receptor alpha-chains (CD25). Breakdown of a single mechanism of self-tolerance causes various autoimmune diseases. J. Immunol. 155, 1151-1164.

Sakaguchi, S., Yamaguchi, T., Nomura, T., and Ono, M. (2008). Regulatory $\mathrm{T}$ cells and immune tolerance. Cell 133, 775-787.

Saraiva, M., Christensen, J. R., Veldhoen, M., Murphy, T. L., Murphy, K. M., and O'Garra, A. (2009). Interleukin10 production by $\mathrm{Th} 1$ cells requires interleukin-12-induced STAT4 transcription factor and ERK MAP kinase activation by high antigen dose. Immunity 31, 209-219.

Satoguina, J. S., Weyand, E., Larbi, J., and Hoerauf, A. (2005). T regulatory-1 cells induce $\mathrm{IgG} 4$ production by $\mathrm{B}$ cells: role of IL-10. J. Immunol. 174 4718-4726.

Schmitt, N., Morita, R., Bourdery, L., Bentebibel, S. E., Zurawski, S. M., Banchereau, J., and Ueno, H. (2009). Human dendritic cells induce the differentiation of interleukin-21producing $\mathrm{T}$ follicular helper-like cells through interleukin-12. Immunity 31, 158-169.

Schreiber, S., Fedorak, R. N., Nielsen, O. H., Wild, G., Williams, C. N., Nikolaus, S., Jacyna, M., Lashner, B. A., Gangl, A., Rutgeerts, P., Isaacs, K., Van Deventer, S. J., Koningsberger, J. C., Cohard, M., Lebeaut, A., and Hanauer, S. B. (2000). Safety and efficacy of recombinant human interleukin 10 in chronic active Crohn's disease. Crohn's Disease IL10 Cooperative Study Group. Gastroenterology 119, 1461-1472.

Scott-Taylor, T. H., J, O. B. H., and Strobel, S. (2010). Correlation of allergen-specific IgG subclass antibodies and $\mathrm{T}$ lymphocyte cytokine responses in children with multiple food allergies. Pediatr. Allergy Immunol. 21, 935-944.

Seddiki, N., Santner-Nanan, B., Martinson, J., Zaunders, J., Sasson, S. Landay, A., Solomon, M., Selby, W., Alexander, S. I., Nanan, R., Kelleher, A., and Fazekas De St Groth, B. (2006). Expression of interleukin (IL)-2 and IL-7 receptors 
discriminates between human regulatory and activated $\mathrm{T}$ cells. $J$. Exp. Med. 203, 1693-1700.

Serafini, G., Andreani, M., Testi, M., Battarra, M., Bontadini, A., Biral, E., Fleischhauer, K., Marktel, S., Lucarelli, G., Roncarolo, M. G., and Bacchetta, R. (2009). Type 1 regulatory $\mathrm{T}$ cells are associated with persistent split erythroid/lymphoid chimerism after allogeneic hematopoietic stem cell transplantation for thalassemia. Haematologica 94, 1415-1426.

Stockis, J., Colau, D., Coulie, P. G., and Lucas, S. (2009). Membrane protein GARP is a receptor for latent TGF-beta on the surface of activated human Treg. Eur. J. Immunol. 39, 3315-3322.

Taga, K., and Tosato, G. (1992). IL-10 inhibits human $\mathrm{T}$ cell proliferation and IL-2 production. J. Immunol. 148, 1143-1148.

Takahashi, T., Kuniyasu, Y., Toda, M., Sakaguchi, N., Itoh, M., Iwata, M., Shimizu, J., and Sakaguchi, S. (1998). Immunologic self-tolerance maintained by CD25+CD4+ naturally anergic and suppressive $\mathrm{T}$ cells: induction of autoimmune disease by breaking their anergic/suppressive state. Int. Immunol. 10, 1969-1980.

Takahashi, T., Tagami, T., Yamazaki, S., Uede, T., Shimizu, J., Sakaguchi, N., Mak, T. W., and Sakaguchi, S. (2000). Immunologic self-tolerance maintained by $\mathrm{CD} 25(+) \mathrm{CD} 4(+)$ regulatory $\mathrm{T}$ cells constitutively expressing cytotoxic T lymphocyte-associated antigen 4. J. Exp. Med. 192, 303-310.

Thornton, A. M., Donovan, E. E., Piccirillo, C. A., and Shevach, E. M. (2004a). Cutting edge: IL-2 is critically required for the in vitro activation of $\mathrm{CD} 4+\mathrm{CD} 25+\mathrm{T}$ cell suppressor function. J. Immunol. 172, 6519-6523.

Thornton, A. M., Piccirillo, C. A., and Shevach, E. M. (2004b). Activation requirements for the induction of $\mathrm{CD} 4+\mathrm{CD} 25+\mathrm{T}$ cell suppressor function. Eur. J. Immunol. 34, 366-376.

Thornton, A. M., Korty, P. E., Tran, D. Q., Wohlfert, E. A., Murray, P. E., Belkaid, Y., and Shevach, E. M. (2010). Expression of Helios, an Ikaros transcription factor family member, differentiates thymic-derived from peripherally induced Foxp3 $+\mathrm{T}$ regulatory cells. J. Immunol. 184, 3433-3441.

Thornton, A. M., and Shevach, E. M. (1998). CD4+CD25+ immunoregulatory $\mathrm{T}$ cells suppress polyclonal $\mathrm{T}$ cell activation in vitro by inhibiting interleukin 2 production. J. Exp. Med. 188, 287-296.

Thornton, A. M., and Shevach, E. M. (2000). Suppressor effector function of CD4+CD25+ immunoregulatory $\mathrm{T}$ cells is antigen nonspecific. J. Immunol. 164, 183-190.

Tilg, H., Van Montfrans, C., Van Den Ende, A., Kaser, A., Van Deventer, S. J., Schreiber, S., Gregor, M., Ludwiczek, O., Rutgeerts, P., Gasche, C., Koningsberger, J. C., Abreu, L., Kuhn, I., Cohard, M., Lebeaut, A., Grint, P., and Weiss, G. (2002). Treatment of Crohn's disease with recombinant human interleukin 10 induces the proinflammatory cytokine interferon gamma. Gut 50, 191-195.

Tran, D. Q., Andersson, J., Wang, R., Ramsey, H., Unutmaz, D., and Shevach, E. M. (2009). GARP (LRRC32) is essential for the surface expression of latent TGF-beta on platelets and activated FOXP3 + regulatory $\mathrm{T}$ cells. Proc. Natl. Acad. Sci. U.S.A. 106, 13445-13450.

Tran, D. Q., Ramsey, H., and Shevach, E. M. (2007). Induction of FOXP3 expression in naive human CD4+FOXP3 $\mathrm{T}$ cells by $\mathrm{T}$-cell receptor stimulation is transforming growth factor-beta dependent but does not confer a regulatory phenotype. Blood 110, 2983-2990.

Tree, T. I., Lawson, J., Edwards, H., Skowera, A., Arif, S., Roep, B. O., and Peakman, M. (2010). Naturally arising human CD4 T-cells that recognize islet autoantigens and secrete interleukin-10 regulate proinflammatory $\mathrm{T}$-cell responses via linked suppression. Diabetes 59, 1451-1460.

Trifari, S., Kaplan, C. D., Tran, E. H., Crellin, N. K., and Spits, H. (2009). Identification of a human helper $\mathrm{T}$ cell population that has abundant production of interleukin 22 and is distinct from $\mathrm{T}(\mathrm{H})-17, \mathrm{~T}(\mathrm{H}) 1$ and $\mathrm{T}(\mathrm{H}) 2$ cells. Nat. Immunol. 10, 864-871.

Trinchieri, G. (2007). Interleukin-10 production by effector $\mathrm{T}$ cells: Th1 cells show self control. J. Exp. Med. 204, 239-243.

Trzonkowski, P., Bieniaszewska, M., Juscinska, J., Dobyszuk, A., Krzystyniak, A., Marek, N., Mysliwska, J., and Hellmann, A. (2009). First-inman clinical results of the treatment of patients with graft versus host disease with human ex vivo expanded CD4+CD25+CD127- T regulatory cells. Clin. Immunol. 133, 22-26.

Veldhoen, M., Uyttenhove, C., Van Snick, J., Helmby, H., Westendorf, A., Buer, J., Martin, B., Wilhelm, C., and Stockinger, B. (2008). Transforming growth factor-beta "reprograms" the differentiation of $\mathrm{T}$ helper 2 cells and promotes an interleukin 9producing subset. Nat. Immunol. 9, 1341-1346.

Veldman, C., Hohne, A., Dieckmann, D., Schuler, G., and Hertl, M. (2004). Type I regulatory $\mathrm{T}$ cells specific for desmoglein 3 are more frequently detected in healthy individuals than in patients with pemphigus vulgaris. J. Immunol. 172, 6468-6475.

Vieira, P., De Waal-Malefyt, R., Dang, M. N., Johnson, K. E., Kastelein, R., Fiorentino, D. F., Devries, J. E., Roncarolo, M. G., Mosmann, T. R., and Moore, K. W. (1991). Isolation and expression of human cytokine synthesis inhibitory factor cDNA clones: homology to Epstein-Barr virus open reading frame BCRFI. Proc. Natl. Acad. Sci. U.S.A. 88, 1172-1176.

Vignali, D. (2008). How many mechanisms do regulatory $\mathrm{T}$ cells need? Eur. J. Immunol. 38, 908-911.

Wang, P., Wu, P., Siegel, M. I., Egan, R. W., and Billah, M. M. (1995). Interleukin (IL)-10 inhibits nuclear factor kappa B (NF kappa B) activation in human monocytes. IL-10 and IL-4 suppress cytokine synthesis by different mechanisms. J. Biol. Chem. 270, 9558-9563.

Wang, R., Kozhaya, L., Mercer, F., Khaitan, A., Fujii, H., and Unutmaz, D. (2009). Expression of GARP selectively identifies activated human FOXP3+ regulatory $\mathrm{T}$ cells. Proc. Natl. Acad. Sci. U.S.A. 106, 13439-13444.

Yagi, H., Nomura, T., Nakamura, K. Yamazaki, S., Kitawaki, T., Hori, S., Maeda, M., Onodera, M., Uchiyama,
T., Fujii, S., and Sakaguchi, S. (2004) Crucial role of FOXP3 in the development and function of human CD25+CD4+ regulatory T cells. Int. Immunol. 16, 1643-1656.

Yamanaka, K., Yuta, A., Kakeda, M., Sasaki, R., Kitagawa, H., Gabazza, E. C., Okubo, K., Kurokawa, I., and Mizutani, H. (2009). Induction of IL-10-producing regulatory $\mathrm{T}$ cells with TCR diversity by epitopespecific immunotherapy in pollinosis. J. Allergy Clin. Immunol. 124, 842-845 e847.

Yssel, H., De Waal Malefyt, R., Roncarolo, M. G., Abrams, J. S., Lahesmaa, R., Spits, H., and De Vries, J. E. (1992). IL-10 is produced by subsets of human CD4+ T cell clones and peripheral blood T cells. J. Immunol. 149, 2378-2384.

Yu, D., Rao, S., Tsai, L. M., Lee, S. K., He, Y., Sutcliffe, E. L., Srivastava, M., Linterman, M., Zheng, L., Simpson, N., Ellyard, J. I., Parish, I. A., Ma, C. S., Li, Q. J., Parish, C. R., Mackay, C. R., and Vinuesa, C. G. (2009). The transcriptional repressor Bcl-6 directs $\mathrm{T}$ follicular helper cell lineage commitment. Immunity 31, 457-468.

Conflict of Interest Statement: The authors declare that the research was conducted in the absence of any commercial or financial relationships that could be construed as a potential conflict of interest.

Received: 14 December 2011; paper pending published: 29 December 2011; accepted: 11 February 2012; published online: 29 February 2012.

Citation: Gregori S, Goudy KS and Roncarolo MG (2012) The cellular and molecular mechanisms of immunosuppression by human type 1 regulatory $T$ cells. Front. Immun. 3:30. doi: 10.3389/fimmu.2012.00030

This article was submitted to Frontiers in $T$ Cell Biology, a specialty of Frontiers in Immunology.

Copyright (C) 2012 Gregori, Goudy and Roncarolo. This is an open-access article distributed under the terms of the Creative Commons Attribution Non Commercial License, which permits noncommercial use, distribution, and reproduction in other forums, provided the original authors and source are credited. 